\title{
A Review on Development of Bio-Inspired Implants Using 3D Printing
}

\author{
Ansheed A. Raheem ${ }^{1}$, Pearlin Hameed ${ }^{1}$, Ruban Whenish ${ }^{1} \oplus$, Renold S. Elsen ${ }^{2}$, Aswin G ${ }^{3}$, \\ Amit Kumar Jaiswal ${ }^{1}$, Konda Gokuldoss Prashanth ${ }^{1,4,5, * \mathbb{C}}$ and Geetha Manivasagam ${ }^{1}$
}

1 Centre for Biomaterials, Cellular and Molecular Theranostics, Vellore Institute of Technology, Vellore 632014, India; ansheed.ar@vit.ac.in (A.A.R.); pearlin.hameed@vit.ac.in (P.H.); wruban1990@gmail.com (R.W.); amitj@vit.ac.in (A.K.J.); geethamanivasagam@vit.ac.in (G.M.)

2 School of Mechanical Engineering, Vellore Institute of Technology, Vellore 632014, India; renoldelsen.s@vit.ac.in

3 School of Advanced Sciences, Vellore Institute of Technology, Vellore 632014, India; ashwinmallesh281@gmail.com

4 Department of Mechanical and Industrial Engineering, Tallinn University of Technology, Ehitajate tee 5, 19086 Tallinn, Estonia

5 Erich Schmid Institute of Materials Science, Austrian Academy of Science, Jahnstrasse 12, 8700 Leoben, Austria

* Correspondence: kgprashanth@gmail.com

Citation: Raheem, A.A.; Hameed, P.; Whenish, R.; Elsen, R.S.; G, A.; Jaiswal, A.K.; Prashanth, K.G.; Manivasagam, G. A Review on Development of Bio-Inspired Implants Using 3D Printing. Biomimetics 2021, 6, 65. https:// doi.org/10.3390/biomimetics6040065

Academic Editor: João F. Mano

Received: 30 September 2021

Accepted: 15 November 2021

Published: 19 November 2021

Publisher's Note: MDPI stays neutral with regard to jurisdictional claims in published maps and institutional affiliations.

Copyright: (c) 2021 by the authors. Licensee MDPI, Basel, Switzerland. This article is an open access article distributed under the terms and conditions of the Creative Commons Attribution (CC BY) license (https:// creativecommons.org/licenses/by/ $4.0 /)$.

\begin{abstract}
Biomimetics is an emerging field of science that adapts the working principles from nature to fine-tune the engineering design aspects to mimic biological structure and functions. The application mainly focuses on the development of medical implants for hard and soft tissue replacements. Additive manufacturing or 3D printing is an established processing norm with a superior resolution and control over process parameters than conventional methods and has allowed the incessant amalgamation of biomimetics into material manufacturing, thereby improving the adaptation of biomaterials and implants into the human body. The conventional manufacturing practices had design restrictions that prevented mimicking the natural architecture of human tissues into material manufacturing. However, with additive manufacturing, the material construction happens layer-bylayer over multiple axes simultaneously, thus enabling finer control over material placement, thereby overcoming the design challenge that prevented developing complex human architectures. This review substantiates the dexterity of additive manufacturing in utilizing biomimetics to 3D print ceramic, polymer, and metal implants with excellent resemblance to natural tissue. It also cites some clinical references of experimental and commercial approaches employing biomimetic 3D printing of implants.
\end{abstract}

Keywords: biomimetic; additive manufacturing; 3D printing; ceramics; polymer; metals

\section{Introduction}

Nature keeps immeasurable innovation and inspirations, which are substantially categorized as visual (shapes and structures) and functional (functionality or multi-functionality) inspirations. Bionic, bio-inspired, bio-mimicry-multiple terms are exclusively owned with regard to nature by borrowing its design or functionality [1]. Derived from a Greek term, the word 'Biomimetics' is the imitation of elements, models, strategies, and systems from nature by solving simple to complex human problems. Nature has optimized and enabled organic structure-function relationships with distinguished physicochemical properties. Embracing sustainable mirroring from nature, biomimetics made an interdisciplinary cooperation and technology transfer to other fields that are seeking problem-solving solutions [2]. Many biomimetic principles, ideas, and concepts are applied to real-life applications due to their tenability, efficiency, and elegant design [3]. Bio-inspired tree branch joints (from pine trees) were adopted in aircraft engineering to improve damage tolerance of aircraft bodies 
using carbon/epoxy composites. Bio-inspired multi-corner tubes copied from bamboo and honeycomb structure are widely applied bio-inspired principles in many engineering problems to enhance the strength of the material without adding any weight [4]. The researchers belonging to a biomimetic group from the University of Toronto expressed four basic research methods for bio-inspired innovations that can be applied to fabricate a product and is depicted in Figure 1 [5]. The ever-growing interest in biomimetics was standardized by ISO 18458:2015. A biomimetic design offers great potential for functional integration, weight-saving and simplifies the design complexities [6].

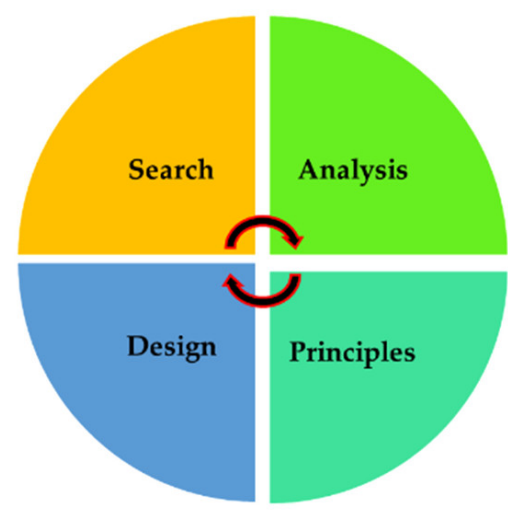

Figure 1. Modus operandi of bio-inspired innovations.

Additive manufacturing (AM), otherwise popularly known as 3D printing or prototyping techniques, has the ability to transform a three-dimensional digital model into functional components irrespective of geometries [7-9]. In the digital manufacturing era, it is possible to achieve ultra-complex structures with enhanced resolution through AM techniques that are extremely difficult to fabricate with conventional machining and molding processes [10-13]. Tool-less manufacturing, supply chain fractionation, design freedom, and ease of automation are some of the key benefits of AM techniques that revolutionize the manufacturing field and pave the foundation for the rapid growth of this sector. Materials, methods, and energy consumption are efficient in AM, creating an inclination towards sustainability in manufacturing [14-16]. AM techniques were introduced to make prototypes, which gradually attained a huge transformation as a reliable direct production technique. The tremendous growth of AM is exhibited in functional component manufacturing for critical applications, such as space exploration, medical device manufacturing, implantology, aerospace development, marine exploration, and defense innovations [17-19]. Light-weight structures with improved mechanical strength and other characteristics processed by AM techniques for aerospace and medical applications are crucial [20-22]. Dynamic development of AM techniques in the market has led to the development of new AM approaches for customizing the respective applications. Additively manufactured parts offer economic manufacturing with superior design performance, which is appraised as an intelligent part design [23,24]. Various materials, such as metals, polymers, ceramics, and composites in the form of powder, filament, resins, and liquids can be reliably processed by AM techniques [25-27]. The fiscal turnover of AM production is obtained through the processing of metals, polymers, ceramics, and others for various applications; among these, polymers are contributing around $80 \%$, and the share of metal printing is also burgeoning due to the biomedical and automotive industry [28-32].

The exponential development of AM and biomimetics can be understood by checking the bibliometrics of published research and review articles in the last ten years. According to the ScienceDirect directory, around 4000 research works concerning 'additive manufacturing' and around 3500 research works related to 'Biomimetics' were published in 2018. In the last five years, 150 published papers on biomimetics-influenced AM techniques depict that this field is one of the fastest-growing research fields. The mutual integration of biomimetic approaches with AM technologies can exist as solution-driven (biology-to- 
design) or problem-driven (design-to-biology) [1,33]. In addition to that, freeform design (customized design), simulation-driven design, and lattice design approaches are practiced for AM fabricated components with varying levels of biological input or bio-inspiration made possible. Biological material has great potential and influences AM with its natureimposed design features, such as fibrous, helical, gradient, layered, tubular, cellular, suture, and overlapping structures. The unique combination, design phenomena, and superior properties of biological components are adopted and employed in various engineering systems on a design or functional basis. AM looks into the design philosophy of green materials, which are considered to be 'eco-designs' because they enable the minimum material usage giving more room for sustainable engineering. The distinctive nature of biological materials, such as hierarchy, multi-functionality phenomena, self-healing, self-assembly, and synthesis, render these materials intrinsically different from synthetic materials [34].

Taking the inspiration from biological materials and their structures, the complex geometries and mechanisms, such as gradient geometries, multi-material, and composite structures, can now be reproduced using AM with advanced chemical and synthesis methods [35]. A few interesting approaches include 'Voronoi diagram' or 'Tessellations,' a generative design approach used for cranial prosthesis designing. Interestingly, a customized and patient-specific cranial implant was designed by mimicking bone trabeculae to reconstruct cranial defects using this approach [36]. Moreover, bio-inspired lattice structures (cellular materials) were employed for an artificial orthopedic hip implant made of Inconel 718 superalloy with a functionally gradient approach [37]. It was observed through finite element analysis that functionally graded lattice structures for the hip implant are appropriate, capable of resisting up to two times the in vivo loads, and are potent to be used as solid implants [38]. When it comes to polymer 3D printing, the thermoset polymer resin is processed by Digital Light Processing for cortical bone reconstruction. Initially, in silico biomimetic models were generated through parametric modeling. From the microstructures, it was understood that the intricate hierarchical structure has acceptable porosity levels [39]. Direct Ink Writing (DIW), an AM approach used to construct viscoelastic ink layer by layer, can be made of hydroxyapatite for engineered bone applications [40].

The central theme of additively-manufactured biomedical constructs is to develop strategies for designing and constructing complex biomedical structures. By embracing a biomimetic approach, AM-based biomedical constructs serve in tissue engineering applications for two broad reasons:

- To replace or repair undermined organs with suitable implanted biomedical constructs.

- To build tissue/organ models for biological analysis and assessment, such as drug screening, toxicity analysis, cell-material interaction.

This review intends to elaborate on additive manufacturing of biomedical implants and their functionalities using polymeric, ceramic, and metallic biomaterials incorporated with biomimetic principles. Clinical trials of biomedical implants illustrated the impact of the biomimetic approach through various case studies and are concluded with future directions.

\section{Ceramic Based AM with Added Functionalities and Application}

Ceramics are considered to be the first explored material for various applications, as their usage date back to 22,000 BC [41]. The multiple classes include oxide and non-oxide ceramics, ceramics composites, glasses, and carbon-based ceramic materials. Alumina, Zirconia, and Silicate are common ceramics that are mostly used in applications requiring high wear resistance, high corrosion resistance, good electrical resistance, and superior thermal stability. Carbon-based ceramic, such as Graphite, Diamond, Graphene, Fullerene, and $\mathrm{CNT}$, are known for their contrast characteristics and diverse applications. Ceramics composites, such as Mullite, Zirconia, toughened Alumina, Carbide Ceramics, and Nitride Ceramics, are also used in manufacturing, biomedical, automobile, and aerospace applications. A separate ceramics band termed bio-ceramics, namely Alumina, Zirconia, Hydroxyapatite (HA), Tricalcium phosphate (TCP), Bio-glass, and Calcium sulfate, are well 
known for their biomedical applications [42]. The processing of all the above mentioned ceramic material offers great challenges due to its brittleness, least fracture toughness, and high melting temperature. Due to the brittleness and low fracture toughness, the machining or forming of ceramics is not possible under normal conditions. The high melting temperature of ceramics demands the need for a high-temperature facility for obtaining finished products. Higher shrinking also leads to difficulties in achieving the final near net shape products. Nevertheless, with all the demerits, they still outperform other materials, which makes them a more interesting material to work with.

With the advent of additive manufacturing (AM), researchers started developing products made of polymers, metals, and alloys [43-46]. In the early days, ceramics-based $3 \mathrm{D}$ printing was difficult due to the extreme process parameter optimization required to develop the products and their fragile properties [47-49]. AM, on the other hand, offers a very high-resolution bottom-up construction of the material, which helps in the extreme control over the process parameters to fine-tune the build. Recently many AM techniques, such as Fused Filament Fabrication (FFF), Digital Light Processing (DLP), Stereolithographic, Inkjet printing, Selective Laser Sintering (SLS), and Selective Laser Melting (SLM), have been adapted for printing ceramics. In addition, a few AM techniques, such as Robocasting [50], Binder Jetting [51], Freeze-form Extrusion Fabrication [52], and Lithography-based Ceramics Manufacturing (LCM) technology [53], are exclusively developed for ceramic printing.

The additive manufacturing of ceramics gained more interest as it has the potential to be developed into biomedical products, mainly implants and scaffolds, which can be made similar to or mimic the actually replaced body tissue. This is achieved by selecting material with identical chemical and physical properties to induce osteoconduction and osseointegration, designing a structure for the scaffold that mimics bone to induce osseointegration, processing, and providing suitable modification in the structure for faster healing. Further, the bio-scaffold should promote vascularization by oxygen transport to cells and the removal of metabolic waste from cells. Thus biomimetic devices fabricated and implanted reduce inflammation and rejection due to immunological responses when implanted in the host. Apart from AM, various conventional manufacturing methods, such as solvent casting/particulate leaching, phase inversion/particulate leaching, icetemplating/freeze-casting, gas foaming, and electrospinning, are also utilized to prepare biomimetic scaffolds. These methods provide biomimetic scaffolds with internal structure, including a pore size between 100 and 1000 microns and porosity up to $90 \%$, resulting in a randomly arranged structure and limited permeability [54-57].

\subsection{Ceramic AM Using Biomimetic Designs}

The design of implants that can lead to the development of implants or scaffolds with properties matching the tissue is of prime importance for the success of the implants and scaffolds. Each organ or tissue in the human body has a unique architecture, and it is mandatory for the human-made materials to mimic this architecture to perform the function of the replaced organ or tissue and provide an apt environment for the surrounding cells to survive. Biomimetic macro/micro-porous alumina scaffolds were successfully printed, and they exhibited a compressive strength of $29 \mathrm{MPa}$, equivalent to the natural bone when measured along the direction of aligned micropores. The inference from biocompatibility studies with the MC3T3 cells suggests that alumina scaffolds offer better cell adherence, cell spreading, good cell viability, and less cytotoxicity [58]. Modulus mismatch between the implant and the surrounding tissues is one of the main reasons for stress shielding in implantology. The Young's modulus human bone ranges from 11 to $20 \mathrm{GPa}$, whereas the E of implants ranges from 55 to $220 \mathrm{MPA}$ and this understating serves as the basis for implant design using additive manufacturing. Efforts have been made to print triply periodic minimal surface (TPMS)-based scaffold using LCM with alumina. It was also proposed that the open-cell structure, as well as the architecture, offer a conducive cell-microenvironment [59]. Zirconia-toughened alumina 3D scaffolds were printed using 
the Robocasting technique, and then after sintering, the porous structures were found to have improved flexibility. The human primary osteoblast was cultured on scaffolds and was found to be consistently dispersed over the whole scaffold thickness [60]. Using FDM fabricated mold microstructure, the alumina and $\beta$-tricalcium phosphate ceramic scaffolds with controlled microstructures of 300 and 480 microns were developed. This being an indirect approach, the compressive strength of the alumina and $\beta$-tricalcium phosphate were reported to be 130 and 1.4 MPA, respectively, for 305 microporous sizes [61]. In the biocompatibility studies, the cells had a good affinity for TCP than alumina structures [61]. From this study, it was well established that mimicking the structure alone will not be sufficient to improve biocompatibility. HA and type-I collagen and HA composite scaffolds have successfully induced osteoblastogenesis and improved mineralization. Moreover, chondrogenesis is found at the center of channeled collagen scaffolds than its outer surface [62]. Apart from mechanical properties mismatch, the surface of current implant materials supports bacterial attachment leading to infection. To combat bacterial infection, a novel electrochemical additive manufacturing method claiming to be cost-effective and time-saving is used to prepare cicada-inspired nanostructured surfaces that are highly antibacterial. The nanopillars structures developed using this technique were found to be closely packed with a diameter of $\sim 65-95 \mathrm{~nm}$ and a height of $\sim 380-510 \mathrm{~nm}$, which promote the antibacterial activity of the surface [63]. It is well-established that the nanopillars with $80 \mathrm{~nm}$ diameters are lethal to gram-negative and positive bacteria, provided the nanopillar density is significant enough to disrupt the bacterial membrane [64].

\subsection{Recent Approaches Using Ceramic Biomimetic AM}

Hydroxyapatite (HA) is well known and used extensively for medical applications as the chemical constituents resemble the bone composition. Compared to micron-sized $\mathrm{HA}$, the nano HA exhibits superior biocompatibility as it resembles the structure of HA crystals in bone [65]. HA nanorods were synthesized using a hydrothermal technique in a type I collagen matrix to mimic bone composition using a 3D bioprinter. However, the strength of the nanorods was reported to be below average [66]. Yongxiang Luo et al. printed Ca7Si2P2O16 using coaxial 3D printing strategy, where hollow-strut structures of bio-ceramic scaffolds with macropores and multi-oriented hollow channels were designed. The scaffold exhibited high porosity and surface area with remarkable strength. It also had improved cell attachment to the scaffold and better cell proliferation and in the center of the scaffolds, further promoting the formation of new bone [67].

HA scaffolds with defined macroporosity were developed employing a powderbased 3D-printing process and post-treated with polymeric infiltration to mimic natural bone with its elastic collagen structure. This scaffold impregnated with biodegradable polymers, such as gelatin, PVA, and PCL, exhibited superior mechanical properties, good bioactivity, and osteoconductivity. The compressive strength of the HA-gelatin composite was observed to be $12.6 \mathrm{MPa}$ [68]. In a different approach, a microscale mask image projection stereolithography technique was used to develop a HA/TCP scaffold of complex geometry with biomimetic features and hierarchical porosity. The scaffold with $30 \mathrm{wt} \%$ $\mathrm{HA} / \mathrm{TCP}$ with biomimetic hierarchical structure exhibited superior mechanical properties of $4.32 \mathrm{MPa}$ when sintered at $1250{ }^{\circ} \mathrm{C}$ with a little over $15 \%$ porosity. The live and dead staining studies carried out at 25 , and $96 \mathrm{~h}$ revealed that this scaffold promotes cell viability as the dead cells were found to be $10 \%$ of the total cell population. The scaffold had sufficient strength for replacing the function of critical load-bearing bone. The in vivo study was performed in a nude mouse with a long bone defect carrying cranial neural crest cells and bone marrow mesenchymal stem cells [69].

In another study by Ewhierarchical, a porous HA biomimetic ceramic 3D-printed scaffold incorporated with covalent, modular, controlled-release system (3DPs) housing BMP2 protein to promote osteogenesis was developed successfully 70.The compressive strength was found to be $9.34 \mathrm{MPa}$. The micro-CT results revealed improved osteointegration and tissue ingrowth. The authors proposed that the scaffold has a therapeutic functionality 
because of which it can ease graft demand [70]. In another study, a laser-aided gelling (LAG) processing of $\mathrm{SiO} 2$-sol mixed with $\mathrm{CaCO} 3$ powder was used to develop scaffolds with inter-pore structures. The highest compressive strength of $47 \mathrm{MPa}$ was reported for $5 \%$ wt. $\mathrm{CaCO} 3$ to $\mathrm{SiO} 2$ slurry. It also exhibited bone cell attachment and growth with nil cytotoxicity. It was reported that it exhibited strength-porosity that mimics human bones [71].

\subsection{Ceramic Processing for Biomimetic AM}

The biomimetic hydroxyapatite/gelatin scaffolds are prepared using robocasting of reactive slurries in a bioinspired low-temperature self-setting alpha-tricalcium phosphate/gelatin ink. The composition, crystallinity, and microstructure are closer to the mineral phase of bone, leading to higher reactivity and resorbability than high-temperature sintered hydroxyapatite. The structure has a controlled and fully-connected pore network of $300 \mu \mathrm{m}$. A higher specific surface area of $22.88 \mathrm{~m}^{2} / \mathrm{g}$ (for gelatin crosslinked) and $24.85 \mathrm{~m}^{2} / \mathrm{g}$ (non-crosslinked) was observed due to micro and nano-porous calcium deficient hydroxyapatite crystals matrix of needle-shape. The compressive strength was 16.6 MPa for the crosslinked scaffolds, $76 \%$ more than the non-crosslinked. However, no significance is found in the stiffness of the scaffolds with $240 \mathrm{MPa}$ for crosslinked and $227 \mathrm{MPa}$ for non-crosslinked. The rMSCs were used, and the cell adhesion and proliferation were found to increase due to the presence of gelatin [72].

$\mathrm{Mg}-\mathrm{HA}$ composite scaffolds of cylindrical shape were printed using 3D printing. The Mg-substituted HA nanoparticles were synthesized from a bi-template induced biomimetic approach by combining type-I collagen and citric acid. Electron microscopic images revealed that the Mg-HA particles had a plate-like morphology with the dimension of 30-50 nm, similar to human bone. The scaffolds were found to have an inter-connected macro-porous structure with a pore size and strut diameter of $400 \mu \mathrm{m}$. The cell adhesion, proliferation, and differentiation studies were performed using MC3T3-E1 cells, which also exhibited promising results. The organic and mineral percent possessed by the human bone was $50-40 \%$ and $50-60 \%$, respectively, which is similar to human bone [73]. Threedimensional-printed HA samples were immersed in $1 \mathrm{M}$ disodium hydrogen phosphate solution for one day at $80{ }^{\circ} \mathrm{C}$, and the influence on biomimetics was cross-checked by assessing the co-deposition by changing soaking time and soaking temperatures, and BSA concentrations. At a $50{ }^{\circ} \mathrm{C}$ soaking temperature, the weight reduces after $16 \mathrm{~h}$ due to partial dissolution of HA with increased temperature. However, at $23^{\circ} \mathrm{C}$ and $37^{\circ} \mathrm{C}$ soaking temperatures, the maximum soaking time reached 24 and $8 \mathrm{~h}$, respectively. It was also observed that there was an inverse relationship between the BSA concentration and the density of the scaffold [74]. In a biomimetic deposition technique, HA samples were 3D printed and then immersed in accelerated calcium phosphate solution (ACS). From the micrographs, it was observed that sharp and interconnected plate-like crystals were grown vertically on the surface of needle-shaped hydroxyapatite crystals. It was reported that the biomimetic approach depends on the crystallization in supersaturation conditions, so competition between crystal nucleation and crystal growth is happening that eventually determines the ultimate crystal structure [75].

\subsection{Ceramic Modifiers for Biomimetic AM}

HA is found to have excellent biocompatibility with host cells and does not provoke an immune response. In vitro and in vivo studies have already proven the extent of biocompatibility this compound has with osteoblasts [76] and mesenchymal stem cells [77]. Moreover, implants coated with HA promote early osteointegration and do not create any inflammatory reactions, according to studies [77]. HA nanoparticles combined with PLLA were printed by the FFF method. The HA nanoparticles were modified with dopamine and hexamethylenediamine, and the PLLA chains were grafted on HA nanoparticles by aminolysis reaction. SEM analysis revealed that the rod and hole widths were 300 and $800 \mu \mathrm{m}$, respectively. The PLLA/HA scaffolds displayed a rougher surface due to extrusion 
swelling. The printed structure had high compressive strength (4 MPa), which supports the proliferation and osteogenic differentiation of osteoblasts [78]. In another approach, the $\beta$-TCP bone tissue scaffolds are designed with pores as a reservoir of Alendronate (osteoporosis treatment drug) are 3D printed using the binder jetting method, and then coated in PCL for a proper release of the drug. The TCP + Alendronate + PCL performed better than the TCP + Alendronate as there was a significant increase in bone formation [79].

Calcium phosphate is an important bone mineral. The bone is the major elemental mineral reservoir that stores $99 \%$ and $80 \%$ of the body's total calcium and phosphate content, respectively, thus making it a suitable compound for developing bio-resorbable products. A 2007 study by Lickorish et al. prepared a third-generation biomaterial exploiting this basic understating, and a polymeric-CaP composite biomaterial was prepared with microporous interconnectivity.

Beta-TCP is reported as the most suitable bio-resorbable material compared to HA and $\alpha$-TCP as it takes just over a month to degrade [80]. The binder jetting method was employed to process Beta-TCP, which exhibits superior osteoconductive abilities with enhanced osseointegration of complex three-dimensional structures. The osteoinduction property of Beta-TCP is reported to be less, and this is enhanced by doping silica and zinc oxide. The dopants modulate collagen-I and osteocalcin production, which boosted the de novo bone formation and neovascularization by three times [81]. The addition of magnesium and silicon to direct 3D printed scaffolds of TCP promotes in vivo osteogenesis and angiogenesis. The printed structure had a total open porosity of $50.21 \%$ after sintering with a pore size of 394 microns, and it exhibited 6.79 MPa compressive strength when sintered at $125{ }^{\circ} \mathrm{C}$ for $2 \mathrm{~h}$. A significantly higher bone and blood vessel formation are observed for the TCP scaffolds with magnesium and silicon from histomorphology, and histomorphometric analysis than plain TCP scaffolds [82]. By combining inkjet printing and freeze-drying methods, porous silk fibroin and bioactive glass composite were fabricated with interconnected structure and controlled architecture. The two levels of pores in the order of 500-600 $\mu \mathrm{m}$ and 10-50 $\mu \mathrm{m}$ were found in the scaffold. The SF-BG scaffolds prepared with microparticles demonstrated a compressive strength of $1.2 \mathrm{MPa}$, slightly better than scaffolds prepared with nanoparticles. However, the scaffold with nanoparticles presented a $50 \%$ hike in the attachment of human bone marrow stem cells compared to microparticles incorporated scaffold [83].

Thus, the 3D printing of ceramic scaffolds is revolutionizing biomaterial manufacturing; however, the design of the biomimetic scaffold depends on factors, such as gender, age, bone defect (size and kind), structural behavior, biochemical stimuli, vascularization, inflammatory and immunological processes, expected during bone regeneration. It should be manufactured based on the type of cells and tissue morphologies of the bone tissue to be restored, thus gaining natural functionalities and displaying ideal biochemical and topographical traits to permit the infiltration of MSCs and other osteoprogenitors cells $[84,85]$.

\section{Polymer-Based AM with Added Functionalities and Application}

Polymers are processed by various AM techniques with added biomimetics approach substantially benefitted for various biomedical applications. Various polymer materials, such as single entity, multi-materials, polymeric composites (with metals, ceramics, and polymer-polymer blends), fillers, coating materials, and functionally graded polymers, are predominantly used for orthopedic bone and dental applications. Apart from these, polymeric nanostructured materials are applied in drug delivery, gene carrying, bioimaging, tissue engineering, and regenerative medicine applications [86]. By promoting biodegradable and recyclable polymers, environmental sustainability could be maintained. Specifically, PLA (Poly Lactic Acid), a popular polymer material that is made from the polymerization of sugars and starches, and polyhydroxyalkanoates (PHA), from sugars with biosynthesis used in Fused Deposition Modelling (FDM), can keep the sustainability criteria. These bio-polymers produce fewer fumes and smells than synthetic petroleum- 
based polymers. In addition to that, adding bio-based fillers can improve sustainability without harming nature. Filler can be fibers or particles, such as sawdust, thermoplastic starches, cellulose fibers, or other natural fibers: bamboo, birch, cedar, cherry, coconut, cork, ebony, olive, pine, or willow reinforced with synthetic polymers to form biocomposites [87]. For instance, lignin, a biomass material from industrial feedstock waste, was added with synthetic polymers acrylonitrile-butadiene-styrene (ABS) and nylon $40-60 \mathrm{wt} . \%$ to promote sustainable development manufacturing. The lignin-based bio-composite exhibits upgraded tensile strength and stiffness at room temperature processed by extrusion-based AM technology called FDM [88]. Sustainable vascularized microtissues were 3D printed for soft tissue repair in vivo as self-assembled building blocks. Aside from tissue repair, such constructs can be used as sustainable in vitro disease models [89].

The elastic nature of intervertebral disk (IVD) tissue was mimicked, and the artificial scaffold was fabricated using the extrusion-based AM technique with degradable polyurethane material. The binder jetting AM technique was adopted to produce loadbearing, porous metallic bone scaffolds, which mimic lamellar plywood motifs for tissue engineering applications [90]. A custom-designed degradable polyurethane (PU) construct was made with the biomimetic elastic nature of the native IVD tissues using an extrusionbased bioprinting technique. The constructs exhibit good elastic nature under compression, similar to native IVD tissues. Precise control over cell morphology, an ideal condition for cell attachment and ECM deposition, and the capability to produce large quantities of tissue scaffolds are key advantages of these material-method combinations [91]. Threedimensional helicoidal structure mimicking the structure found in mantis shrimp was used to develop lab-scale 3D biomimetic tough helicoidal structure using polycaprolactone (PCL) and polyvinylidene fluoride (PVF) fabricated through novel near-field electrospinning technique (NFES). The results showed that bio-inspired helicoidal structures provide a high load-carrying capacity and better crack and delamination resistance [34]. Figure 2 represents the polymeric components used in biomedical applications fabricated by AM techniques with biomimetic functionality.

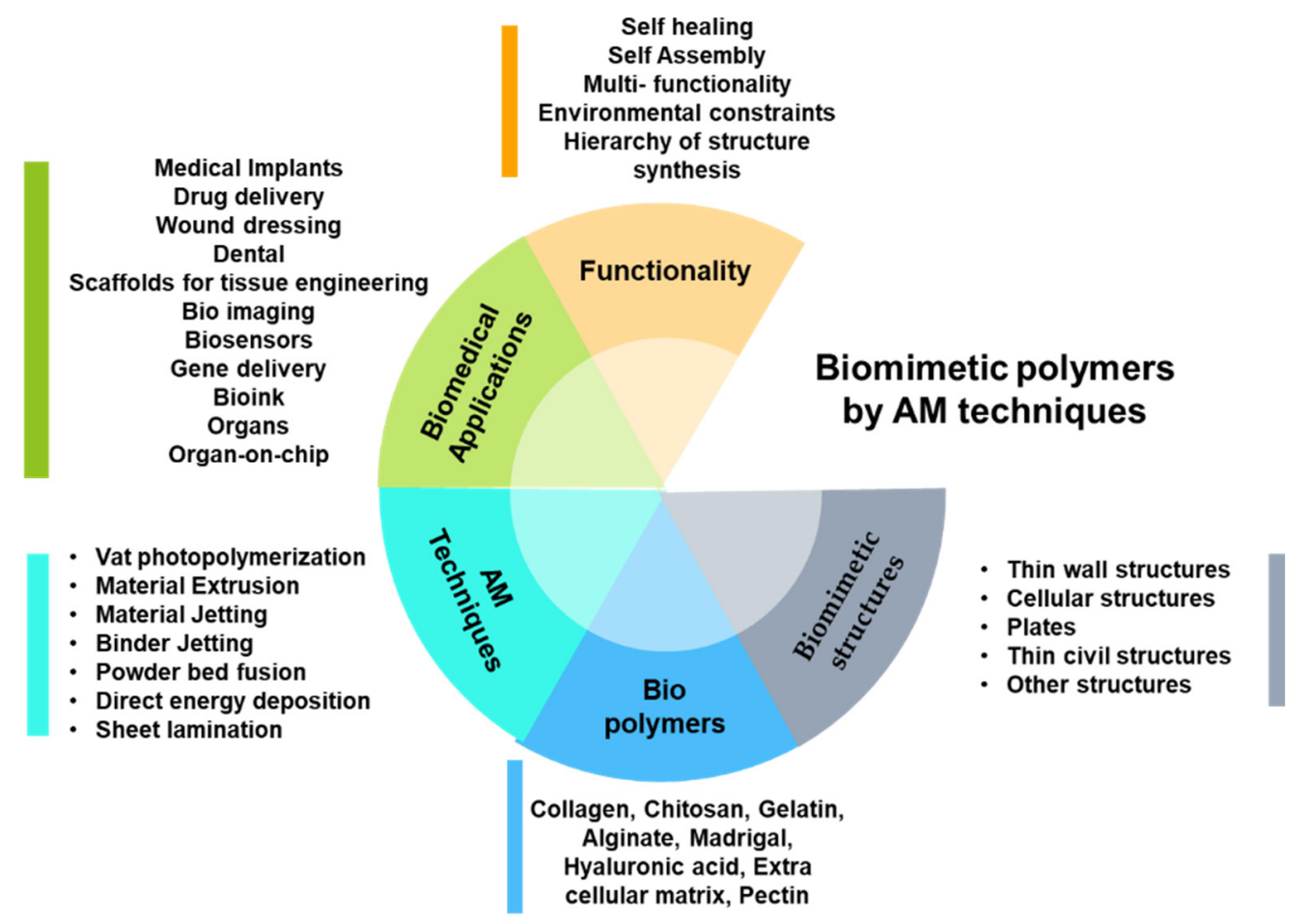

Figure 2. Polymers with biomimetic functionalities processed by AM techniques.

Alginate is used as a hydrogel for the bio-fabrication process. It has strong mechanical properties for ideal bio-fabrication. In another study, alginate was combined with nano- 
cellulose and used as a bio-ink $[64,65]$ to assess the biocompatibility with human nasoseptal chondrocytes. An extrusion-based 3D bioprinter printed this combination with optimized process parameters. Alginate-nano-cellulose bio-ink demonstrated post-printing shape fidelity (reversible stress softening behavior), a high degree of shear thinning, and a stable construct volume [66]. Photopolymerizable polymer (composed of urethane acrylate oligomers) was designed with cellular structures with four precisely controlled internal architectures (octahedral, cubic octahedral, pillar octahedral, and truncated octahedral) for biomimetic bone implants. The implants were fabricated by 3D printing technologies and evaluated for their biological and mechanical behavior. Among the four internal architectures, it was found that the pillar octahedral had balanced mechanical and biological properties [92]. The evolution of nature-derived polymer-based new products with a biomimetic approach yields sustainable development in additive manufacturing. Table 1 represents the biomimetic polymers used in functional biomedical applications fabricated through AM techniques.

Hybrid AM processing was amended for dental applications using metal and polymer materials. The SLM process was used to produce a metal mesh of dental implant, and it was placed in the SLA platform. The photosensitive polymeric resin fills the core and coats around the tooth for the teeth crowns. The metal-polymer gradient multi-material successfully manufactured by SLM/SLA hybrid AM techniques by adopting the biomimetic approach exhibits good biomechanical strength. This approach was espoused to manufacture bio-inspired patient-specific dental implant cores using metal, ceramic, polymer, or composites, which exhibited superior performance. Furthermore, dental crowns are coated with polymeric materials to obtain good physicochemical and biomechanical characteristics [93]. The feasibility of mimicking the natural curvature and dimensions of human cell membrane models, i.e., red blood cells, smooth muscle cells, and columnar epithelial cells with microvilli, has also been assessed. These cells have been chosen with distinctive features, shapes, and sizes and produced through two-photon polymerization additive manufacturing using polymeric cell scaffolds and coated with the cationic polymer PLL (Polylysine). The model can reproduce human cell-like shapes with high fidelity, suitable for incorporating transmembrane proteins and useful tool for drug delivery studies [94].

Table 1. Polymer, biomimetic functions, AM techniques, and biomedical applications.

\begin{tabular}{|c|c|c|c|c|}
\hline Polymers & $\begin{array}{l}\text { Biomimetic } \\
\text { Functionality }\end{array}$ & $\begin{array}{l}\text { Biomedical } \\
\text { Application }\end{array}$ & $\begin{array}{l}\text { AM Processing } \\
\text { Technique }\end{array}$ & Advantages \\
\hline \multicolumn{5}{|c|}{ Natural polymers (proteins and polysaccharides) } \\
\hline Collagen [95] & $\begin{array}{l}\text { Biomimicking native } \\
\text { tissue }\end{array}$ & $\begin{array}{l}\text { Skin replacement, } \\
\text { hydrogel, bioink }\end{array}$ & Extrusion, Fusion & $\begin{array}{c}\text { Mechanical stiffness, } \\
\text { viscosity, } \\
\text { biodegradability }\end{array}$ \\
\hline Gelatin [96] & $\begin{array}{l}\text { Biomimicking native } \\
\text { tissue }\end{array}$ & Bioink, hydrogel & $\begin{array}{l}\text { 3D Bioprinting, SLA, } \\
\text { extrusion, inkjet } \\
\text { printing, 4D printing, } \\
\text { Laser printing }\end{array}$ & $\begin{array}{c}\text { Biocompatible, } \\
\text { biodegradable, flexible }\end{array}$ \\
\hline $\begin{array}{c}\text { Chitosan-HAp } \\
\text { (hydroxyapatite) [97] }\end{array}$ & $\begin{array}{l}\text { Biomimicking native } \\
\text { tissue }\end{array}$ & $\begin{array}{c}\text { Hydrogel, scaffolds, } \\
\text { bone tissue engineering }\end{array}$ & 3D printing & $\begin{array}{l}\text { Biocompatible, cell } \\
\text { viability, cell-friendly } \\
\text { environment, adequate } \\
\text { mechanical properties }\end{array}$ \\
\hline Hyaluronic Acid [98] & $\begin{array}{l}\text { Biomimicking native } \\
\text { tissue }\end{array}$ & $\begin{array}{l}\text { Hydrogel in cartilage } \\
\text { regeneration }\end{array}$ & 3D printing & $\begin{array}{l}\text { Superabsorbent, } \\
\text { cytocompatible }\end{array}$ \\
\hline Alginate [99] & $\begin{array}{l}\text { Biomimicking native } \\
\text { tissue }\end{array}$ & Bioink, hydrogel & $\begin{array}{l}\text { Bioprinting, extrusion } \\
\text { printing }\end{array}$ & $\begin{array}{l}\text { Cell-protective effect, } \\
\text { cell viability }\end{array}$ \\
\hline Silk Fibroin [99] & $\begin{array}{l}\text { Biomimicking native } \\
\text { tissue }\end{array}$ & Scaffold, bioink & $\begin{array}{l}\text { Bioprinting, extrusion } \\
\text { printing }\end{array}$ & $\begin{array}{c}\text { Superior mechanical } \\
\text { properties and tunable } \\
\text { degradability }\end{array}$ \\
\hline Fibrin ink & $\begin{array}{l}\text { Biomimicking native } \\
\text { tissue }\end{array}$ & Vascular constructs & Inkjet printing & [100] \\
\hline
\end{tabular}


Table 1. Cont.

\begin{tabular}{|c|c|c|c|c|}
\hline Polymers & $\begin{array}{c}\text { Biomimetic } \\
\text { Functionality }\end{array}$ & $\begin{array}{l}\text { Biomedical } \\
\text { Application }\end{array}$ & $\begin{array}{l}\text { AM Processing } \\
\text { Technique }\end{array}$ & Advantages \\
\hline \multicolumn{5}{|c|}{ Synthetic polymers } \\
\hline $\begin{array}{l}\text { Polycaprolactone } \\
\text { (PCL) [101] }\end{array}$ & $\begin{array}{c}\text { Biomimicking native } \\
\text { tissue, } \\
\text { multi-functionality }\end{array}$ & $\begin{array}{l}\text { Tissue engineering } \\
\text { wound dressing }\end{array}$ & FDM & $\begin{array}{l}\text { Low melting point, } \\
\text { Biocompatible }\end{array}$ \\
\hline Polyurethane (PU) [91] & $\begin{array}{l}\text { Biomimicking native } \\
\text { tissue }\end{array}$ & $\begin{array}{l}\text { Tissue engineering, } \\
\text { prosthetic devices }\end{array}$ & Binder Jetting, FDM & Elasticity \\
\hline $\begin{array}{l}\text { Polyether ether ketone } \\
\text { (PEEK) [102] }\end{array}$ & $\begin{array}{l}\text { Biomimicking native } \\
\text { tissue }\end{array}$ & $\begin{array}{c}\text { Dental, orthopedic, } \\
\text { trauma, and spinal } \\
\text { implants }\end{array}$ & $\begin{array}{l}\text { Laser printing, } \\
\text { extrusion }\end{array}$ & $\begin{array}{l}\text { Superior mechanical } \\
\text { properties, inert, } \\
\text { biocompatible }\end{array}$ \\
\hline $\begin{array}{l}\text { Polyethylene } \\
\text { glycol [103] }\end{array}$ & $\begin{array}{l}\text { Biomimicking native } \\
\text { tissue }\end{array}$ & $\begin{array}{l}\text { Porous scaffold, } \\
\text { Implants, Drug } \\
\text { delivery }\end{array}$ & Extrusion & Biocompatible \\
\hline $\begin{array}{l}\text { Polylactic acid } \\
\text { (PLA) [104] }\end{array}$ & $\begin{array}{l}\text { Biomimicking native } \\
\text { tissue }\end{array}$ & $\begin{array}{c}\text { Scaffolds, prosthetic } \\
\text { devices }\end{array}$ & $\begin{array}{l}\text { Extrusion based } \\
\text { bioprinting }\end{array}$ & Mechanical strength \\
\hline $\begin{array}{l}\text { Acrylonitrile butadiene } \\
\text { styrene (ABS) }[105,106]\end{array}$ & Functional models & $\begin{array}{c}\text { Prototypes, } \\
\text { cost-effective prosthetic } \\
\text { devices }\end{array}$ & Extrusion & Low cost \\
\hline \multicolumn{5}{|c|}{ Polymer composites } \\
\hline $\begin{array}{l}\text { Polyethylene glycol } \\
\text { (PEG) derivatives } \\
\text { mixed with } \\
\text { fibroblasts [107] }\end{array}$ & $\begin{array}{l}\text { Hollow tubular } \\
\text { structures }\end{array}$ & Vascular constructs & Extrusion & Biocompatible \\
\hline $\begin{array}{c}\text { Polyglycolic } \\
\text { acid/polylactic acid } \\
\text { (PLA/PGA) } \\
\text { scaffolds [108] }\end{array}$ & $\begin{array}{l}\text { Native stiff bone-like } \\
\text { constructs }\end{array}$ & Cartilage-Bone & 3D Printing & Biocompatible, stiffness \\
\hline $\begin{array}{l}\text { polyethylene glycol } \\
\text { (PEG) / } \beta \text {-tricalcium } \\
\text { phosphate }(\beta-\mathrm{TCP}) \\
\text { scaffold }[109]\end{array}$ & $\begin{array}{l}\text { bio-inspired interface } \\
\text { structures }\end{array}$ & Cartilage-Bone & Stereolithography & Biocompatible \\
\hline $\begin{array}{l}\text { PLA/HA screw-like } \\
\text { scaffold [110] }\end{array}$ & Native bone & Bone & 3D Printing & $\begin{array}{c}\text { Bio-active, mechanical } \\
\text { properties }\end{array}$ \\
\hline $\begin{array}{c}\text { Chitosan-based } \\
\text { polymers (N-succinyl } \\
\text { chitosan grafted } \\
\text { polyacrylamide [111] }\end{array}$ & $\begin{array}{l}\text { Shape memory } \\
\text { function }(\mathrm{pH})\end{array}$ & $\begin{array}{l}\text { Drug delivery; Bone } \\
\text { regenerative therapies }\end{array}$ & 4D Printing & $\begin{array}{l}\text { Biocompatible, Better } \\
\text { controlled release of } \\
\text { drugs; Tunable } \\
\text { mechanical properties }\end{array}$ \\
\hline $\begin{array}{l}\text { Gelatin- } \\
\text { polycaprolactone } \\
\text { (PCL) [112] }\end{array}$ & tubular structures & $\begin{array}{l}\text { Bilayers, Cell-laden } \\
\text { bioscaffolds for tissue } \\
\text { engineering }\end{array}$ & 4D Printing & $\begin{array}{l}\text { Compatible; } \\
\text { Biodegradable }\end{array}$ \\
\hline $\begin{array}{l}\text { Poly-ethylene glycol } \\
\text { (PEG) [113] }\end{array}$ & $\begin{array}{c}\text { Shape memory } \\
\text { function (Humidity) }\end{array}$ & Cell-laden bilayers & 4D Printing & Biocompatibility \\
\hline
\end{tabular}

\section{Metal-Based AM with Added Functionalities and Application}

Implantology dates back to the pre-Columbian era, with some of the early mentions around $2500 \mathrm{BC}$ regarding the use of gold ligatures for teeth stabilization [114]. Since then, metal has been the most preferred material for load-bearing implant construction, other than early implant materials, such as ivory, rubber, and even animal bone [115]. Metals are inert, biofriendly, have good strength, higher fracture toughness, wear, and corrosion resistance, decent fatigue-proof hardness, and excellent for all load-bearing applications [116]. Metallic biomaterials were considered a suitable replacement for treating bone defects. The most commonly used metallic biomaterials are constructed using stainless steel (SS), cobalt alloys, magnesium alloys, pure titanium, and its alloys with vanadium, nickel, silver, 
tantalum, and zirconium [117-120]. However, all conventional metal implants were poor in mimicking the native properties of human bone, leading to further complications in the long run. One of the major drawbacks is their surplus elastic modulus, which leads to stress shielding, a phenomenon in which implants with high elastic modulus and tensile strength (such as Titanium or SS) create an uneven bodyweight distribution, leading to bone loss or osteopenia over the long run [121]. Resorbable elements, such as Iron or Magnesium, get absorbed into the body, causing premature weakening or loss of implant strength [122]. Alloy implants, such as Ti- $15 \mathrm{Zr}-10 \mathrm{Cr}$ or Ti-6Al-4V have been found to release vanadium or chromium ions into human cells, leading to cytotoxicity [123]. Some of these challenges can be addressed if the choice of material and its processing could give a more biomimicking implant that deviates very little from the natural organ that is being substituted.

It has been observed that the success rate of any implantation is highly dependent on biomimetics. Say, for example, the healing of bone through direct or indirect mechanisms is a complex biological process, and a bone implant substituting a defect has to be designed in such a way that it should promote natural bone healing by triggering mesenchymal stem cells recruitment, generation of callus, revascularization, neoangiogenesis, mineralization of new bone, and finally remodeling [124]. Fortunately, the research world is putting efforts into addressing the abovementioned aspects during the manufacturing stage, and additive manufacturing (AM) is a promising approach with very high biomimetic capability. Additive manufacturing (3D printing or rapid prototyping or rapid manufacturing) is a three-decade-old bottom-up fabrication approach that is currently in the vanguard of biomaterial processing. Metal AM is found to be an efficient processing technique to fabricate implants with very high precision and patient specificity. The next section will substantiate the importance of AM in promoting biomimetics in implants.

\subsection{Importance of AM in Construction of Biomimicking Implants}

$\mathrm{AM}$ is an emerging material processing technique that can revolutionize implantology, especially for hard implants. Since this is a computerized bottom-up technique, there is fine control over the anatomical features of the lost tissue and can even imitate the micro and nano-level topographical features of the bulk material used for implant processing. Usually, the site of injury is scanned using Computer Tomography (CT) or Magnetic Resonance Imaging (MRI) to obtain Digital Imaging and Communications in Medicine (DICOM) data, and with the help of CAD or modeling software, the replica of the lost tissue is designed (cross-check this). The 3D printer stacks the metal feed in a series of layers based on the software input to create complex and patient-specific structures. This facile processing technology made it much more cost-effective than the conventional approach and made it a burgeoning orthopedic repair mechanism. There are various materials used in implanting, of which metals are best suited for the load-bearing application, thus becoming the gold standard for orthopedic repair and corrections. AM allows the existing metal modeling for biomedical applications to be more bio-friendly and mimicking.

\subsubsection{Mimicking Mechanical Properties of Natural Bone}

Apart from the technological superiority of the process, AM helps overcome the two important shortcomings with the conventional bio-inert implants, i.e., poor osteointegration and stress shielding. A study by Sajad et al. had clearly demonstrated the importance of implant architecture and dexterity of AM in overcoming this limitation [125]. AM mimics the natural architecture of the human bone, thanks to the computer-assisted layer-by-layer stacking with precise control over the size and porosity of the implant material. This porous nature of the material reduces the elastic modulus of the implant, making it comparable to that of natural bone, thus preventing the stress shielding effect [126]. In a 2015 study by G. Rotta et al., it was demonstrated that SLM-printed porous Ti-6Al-4V had an 85\% reduction in elastic modulus. The conventional alloy had a modulus of $110 \mathrm{GPa}$, while the 3D-printed porous Ti-6Al-4V showed a range of 17-49 GPa, which stands closer to actual human bone, varying from 0.15 to $18.1 \mathrm{GPa}$ [127]. A study by Hasan et al. suggests that shell 
thickness and porosity parameters for AM is also an important aspect for ensuring adequate mechanical properties [128]. A comparison of the tensile strength and elastic modulus of the natural bone, conventional bone implants, and AM porous implants is given below in Table 2 [96,116,129-134]. Three-dimensional printing allows the user to have fine control over mechanical parameters, such as cross-sectional shape and rod diameter, which can influence the porosity, which is an important parameter necessary for biomimicking the actual bone. It ensures the circulation of necessary nutrients, oxygen, and other biological components to initiate bone healing post-implantation. It has been observed that a pore size ranging from 300 to $800 \mu \mathrm{m}$ is the ideal porosity for mimicking human bone [135]. It has been observed that changing porosity and microstructure can influence the regeneration of bone [136-138].

Table 2. Tensile strength and elastic modulus of human bone, and common biomaterials (conventional vs. AM) $[17,19,20,27,29,32,33,49,132,139,140]$.

\begin{tabular}{llcc}
\hline & \multicolumn{1}{c}{ Materials } & Tensile Strength (MPa) & Elastic Modulus (GPa) \\
\hline & \multicolumn{3}{c}{ Natural Bone } \\
\hline a. & Tibia & 140 & 18.1 \\
b. & Femur & 121 & 17.2 \\
c. & Radius & 149 & 18.6 \\
d. & Humerus & 130 & 17.2 \\
e. & Cervical & 3.1 & 0.23 \\
f. & Lumbar & 3.7 & 0.16 \\
\hline & & Conventional Metals / Alloys & \\
\hline a. & CP Ti & 785 & 105 \\
b. & Ti-6Al-4V & 970 & 110 \\
c. & Ti-6Al-7Nb & 1024 & 105 \\
d. & Stainless steel 316L & $460-950$ & 200 \\
e. & Co-Cr alloys & $655-1896$ & $210-250$ \\
\hline & & AM Porous Metals/Alloys & \\
\hline a. & CP Ti & $78-245.5$ & $5.5-8.5$ \\
b. & Ti-6Al-4V & $64-409$ & $3.8-7.8$ \\
c. & Ti-6Al-7Nb & 105 & $1.2-4-5$ \\
d. & Stainless steel 316L & 300 & $0.15-0.12$ \\
e. & Co-Cr alloys & $60-150$ & $20-25$ \\
\hline
\end{tabular}

One of the interesting features of AM is its ability to control and design the lattice structure and gradient structure, which has a critical role in determining the success rate of the implant inside the body. The arrangement of unit cells in a periodic fashion was effective in predicting the performance of the implant and improving the reproducibility and ease of manufacturing. Some of the commonly used lattice structures are the polyhedral models (circular or square), bidirectional evolutionary structural optimization (BESO), multi-phase topology optimization (MPTO), and triply periodic minimal surfaces (TPMS), which stand close to human bone's lattice arrangement. Natural bone has a varying lattice arrangement throughout its length, as shown in Figure 3. Focusing on lattice parameters alone is not necessary to mimic the actual bone; therefore, in the latest effort, researchers focus on functionally graded materials (FGM), which can accommodate varying lattice arrangements and have adaptive porosity. Figure 4 demonstrates some of the common unit cell structures that can mimic the porosity of natural bone. 


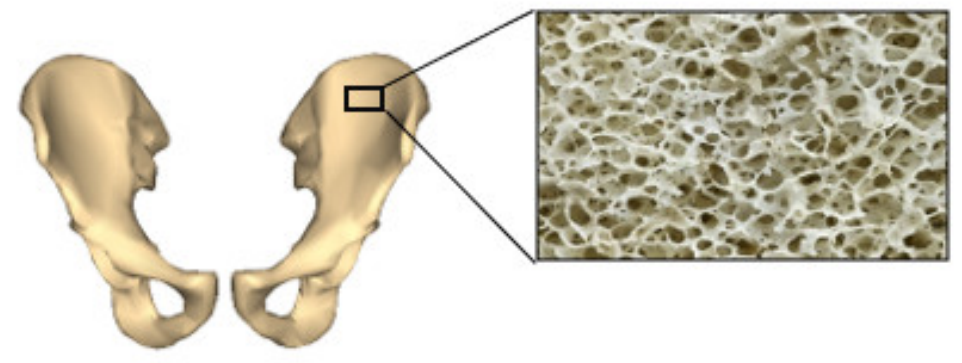

Figure 3. Porosity in natural bone. Anatomography, CC BY-SA 2.1, JP [139] I Patrick CC BY 2.0, USA [140].
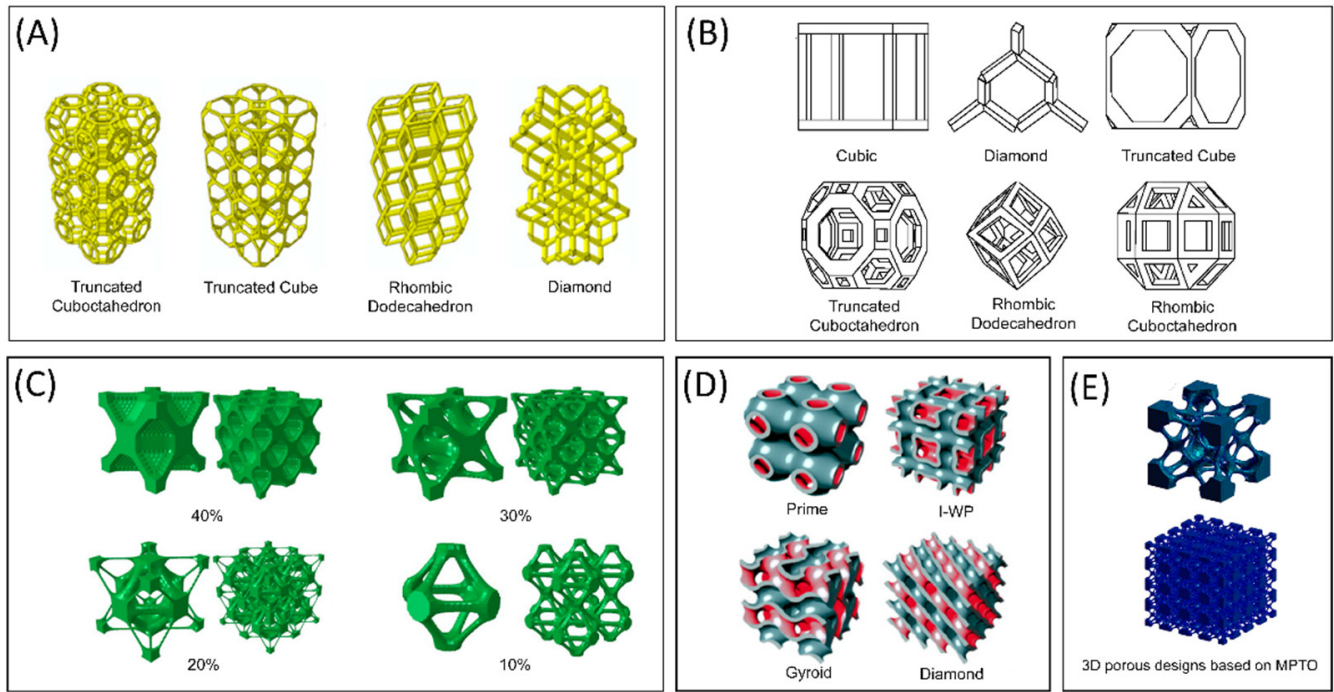

Figure 4. Commonly used unit cell structures for mimicking bone architecture in additive manufacturing. (A) Polyhedral circular geometry (B) Polyhedral square geometry (C) Bidirectional evolutionary structural optimization (BESO) based unit cell geometry (D) Triply periodic minimal surfaces (TPMS) based geometry (E) Multi-phase topology optimization (MPTO) based three-dimensional porous structures. Adopted, recreated, and reprinted under Creative Common CC BY license from, https:/ / www.mdpi.com/2075-4701/9/9/1004/htm [136].

\subsubsection{Surgical Planning}

AM is a simple technique that can create 3D models and guides for surgical planning, which helps doctors make a spot-on analysis pre and post-implantation. Since the design aspect is computer-aided, the surgeon gets a tactile and in-depth understanding of the complex fracture pattern that occurred to the bone. Unlike traditional implantation procedures, the surgeon can have a readymade patient-specific implant model in hand for pre-operative review to plan for intraoperative complications, which is crucial in surgery planning [141,142]. Some of the projected benefits of this approach are improved patient communication, shorter operative time, higher precision in the alignment of components, and a 3D model that acts as a patient-specific reference that improves the safety of the procedure [143]. Three-dimensional models of bone are currently used in the surgical planning of upper and lower limb osteotomies and the correction surgery of diseases, such as spine scoliosis, Blount's disease, and Perthes disease [144,145].

\subsection{Conventional Metal Processing and Its Biomimetics}

In earlier days, bone defects were repaired using autografting from the cranium, tibia, rib, scapula, sternum, fascia, or ileum were used [126]. In later approaches, allografts (of cadaveric origin) and xenografts from animals were used for cranioplasty [127,128]. However, maintenance, revision surgery, and graft rejection are some of the problems with 
the above techniques [126]. This led to the use of non-metallic and metallic allografts in rural surgical practice. The bone defect was fixed in the conventional approach using a metal plate or mesh, synthetic bone substitute, or prefabricated bone replacements [129]. Metal allografts made from gold and silver were early contenders, but later, other metals, such as aluminum, tantalum, stainless steel, lead, platinum, vitallium, ticonium, and titanium, were used [126,130-132]. However, most of these metals had several mechanical and chemical issues to be used as an implant. For example, pure metals were prone to oxidative or galvanic corrosion, while common metals, such as stainless steel, had high stiffness leading to stress shielding and other inflammatory response due to the conductivity of the oxide layer $[133,134]$. Due to the excellent biomimetic capability and biocompatibility, titanium alloys have come up as a suitable implant choice [134].

Conventional metal processing techniques include machining forged titanium alloys according to orthopedic design needs. However, this technique results in a lot of material wastage, and the incorporation of complex anatomical design features is not possible with machining [135]. Precision casting is another favorable technique, but the high melting point of titanium $\left(>1700^{\circ} \mathrm{C}\right)$, fluid properties, and faster oxidation make this a challenging processing technique. Some advanced techniques, such as centrifugal precision casting, have been devised but are not an economically viable choice to manufacture porous implants to mimic natural bone architecture [136]. Deep rolling and cold rolling is considered effective alternative against shot-peened titanium; however, rolling techniques are highly limited by their shape choices [137]. Friction stir processing (FSP) is an advanced manufacturing technique in which localized plastic deformation is induced to change the mechanical properties of metal. FSP processed Ti-6Al-4V with surface modifications shows improved cellular adhesion; however, it also has drawbacks similar to conventional techniques [138]. The bulk mechanical property is not changed to match the natural elastic modulus of bone.

All existing implant manufacturing processes can fabricate the bulk material; however, the crux of biomimetics is a combination of biocompatibility, bioactivity, and immune acceptance. The first and foremost requirement for biomimicry is to choose a material accepted by the immune system. Once that is taken care of, the next is to mimic the physical architecture of the tissue (bone) to house the biochemical components. All conventional techniques fail in the second part, where the processing limitations prevent them from copying the actual physical and mechanical properties of natural human bone. This is where additive manufacturing of hard metals gains its superiority. Since the implant is constructed layer-by-layer, there is room for copying the micro or nano-architecture of real bone. The level of detail is currently limited to some of the basic unit cell designs as discussed above but is expected to incorporate the natural design in the near future. Incorporating bioactive elements, such as $\mathrm{Zn}, \mathrm{Sr}, \mathrm{Mg}, \mathrm{Nb}$, during the alloying process is the first step towards making the implant bioactive [139].

\subsection{Techniques Used for Metal Powder Bed Fusion}

Out of the vast plethora of Additively manufacturing (AM) techniques, metallic printing occupies a substantial fraction in the 3D printed market, as reported by a market analysis report 2020 [146]. The automobile, aerospace, healthcare, and consumer products are major sectors exploiting additive manufacturing products to the fullest. The espousal of metal AM technology, mentioned in Table 3, such as Selective Laser Melting (SLM), Electron Beam Melting (EBM), Direct Metal Laser Sintering (DMLS), Laser Engineering Net Shaping (LENS), and Directed Energy Deposition (DED), by manufacturing industries has enabled the rapid fabrication of tailor-made components and products. AM has also reduced the factory to market time. These contemporary techniques give a tough competition to the conventional fabrication techniques, such as casting, forging, and metal injection molding.

An overview of the different AM techniques used for metal printing is shown in Figure 5. Each of these additive manufacturing techniques, SLM, EBM, DMLS, and LENS/DED, differ slightly from one another. Still, most of these techniques have a com- 
mon factor: laser and a similar powder recoating mechanism, except in EBM, which uses electron-beam. Briefly, in all metal additively manufacturing techniques, a laser or an electron beam melts the powder metal particles to fuse the molten metal for a structure layer by layer. The following powder layer spreading mechanism onto the substrate or build plate differs from technique to technique. For example, in SLM, DMLS, and EBM, a re-coater/wiper spreads the powder, while in the case of DED/LENS, the powder is emitted from a nozzle reducing the wastage of powder. The powder is applied and melted, and this process is repeated slice by slice until the part is entirely printed.

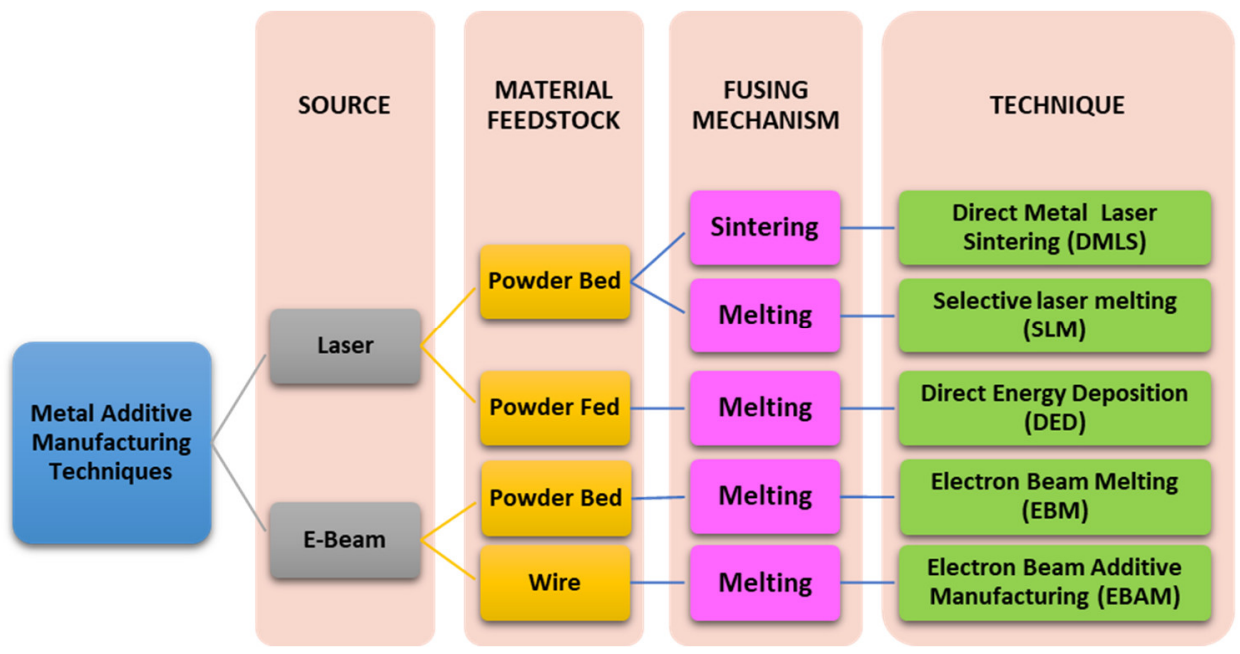

Figure 5. Different metal additive manufacturing techniques.

Table 3. A brief overview of different metallic additive manufacturing techniques.

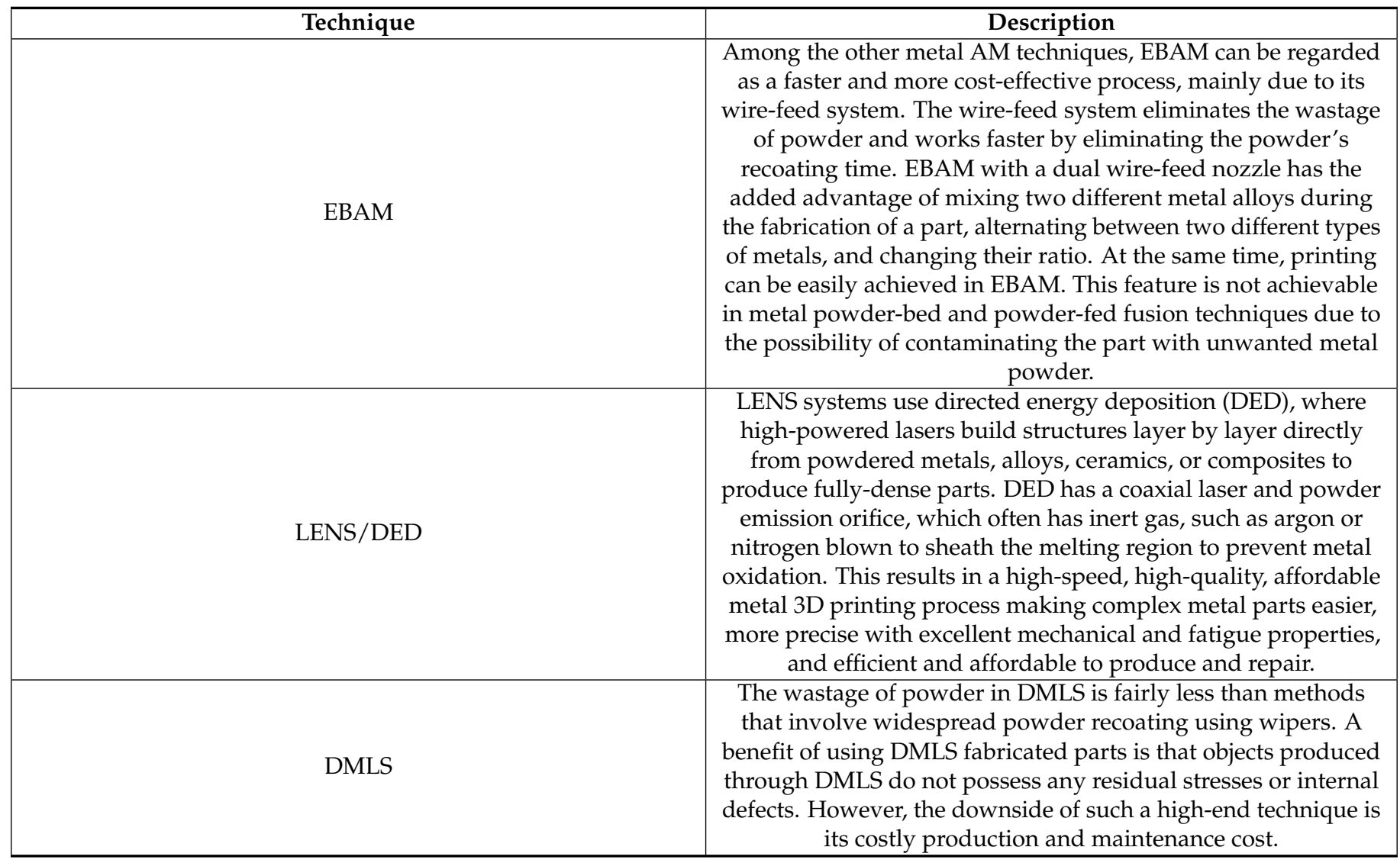


Table 3. Cont.

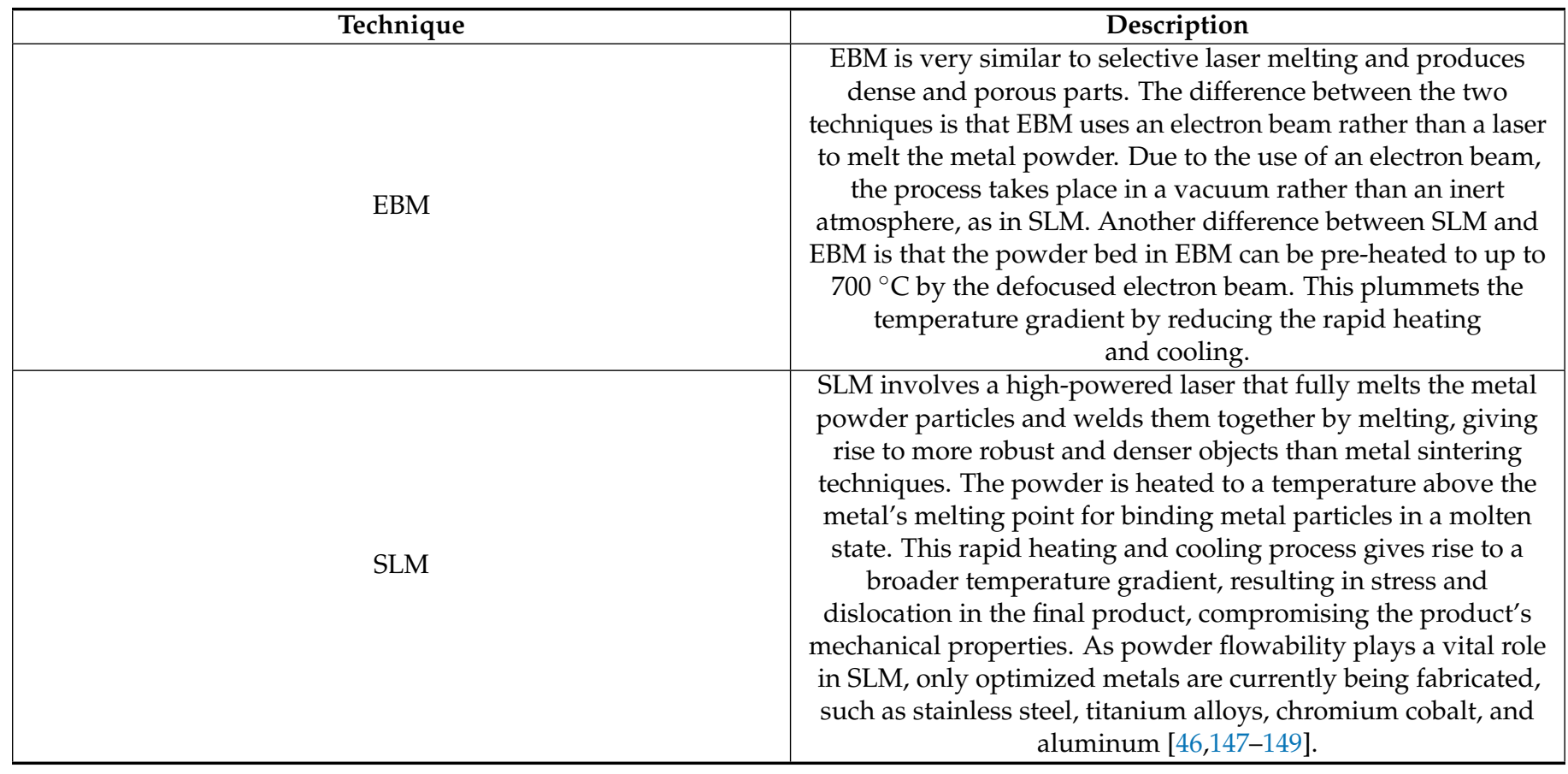

\subsection{Post-Processing of AM Products}

The melting of metallic powder at high temperatures during different additive manufacturing techniques makes it unfeasible to add bioactive and organic elements during the process. The probability of these elements losing their property while getting melted or welded during the manufacturing process is inevitable. Thus, a 3D printed object has a greater chance of modifying/functionalizing during post-processing than in situ processing. The post-processing workflow is depicted in Figure 6. The first step to post-processing of the manufactured product involves stress relieving. The recurrent cooling and melting of metal powder at a rapid rate cause internal stress build-up within the built product, which must be relieved before the part is separated from the build plate. The presence of residual stress in the final product can lead to distortion and, in extreme cases, might lead to the formation of cracks while intrinsic properties, such as fatigue and tensile strength, are also affected [150,151]. The common method for reducing the residual stress before fabrication involves pre-heating feedstock powder and substrate and changing the scanning strategy [152]. In comparison, the post-built method involves annealing the part in an inert atmosphere. Alternatively, researchers have also developed an in situ method for reducing stress during fabrication by illuminating the building part with homogeneous intensity emitted by laser diodes. This process decreased the large thermal gradient, resulting in a $90 \%$ reduction in residual stress [151].

The second step of post-processing involves removing support structures to extricate the parts from the build plate. This can be done manually with the help of pliers or using machines, such as bandsaw and wire EDM. This is followed by heat treatment of the built parts to modify the mechanical properties (yield strength, corrosion resistance, ductility) and rearrangement of microstructure and phase distribution [153-155]. ASTM F3301-18a provides a detailed guideline and standard for thermal post-processing methods. This step is followed by machining and polishing, which allows modification of the built product to give a more finished look. It involves removing internal support structure, grinding and smoothing, adding treads, chemical and electrochemical polishing, deburring using centrifugal disc finishing or water jet blasters, abrasive blasting, and shot peening ultrasonic cavitation abrasive finishing, and CNC and vibratory finishing [156-158]. 


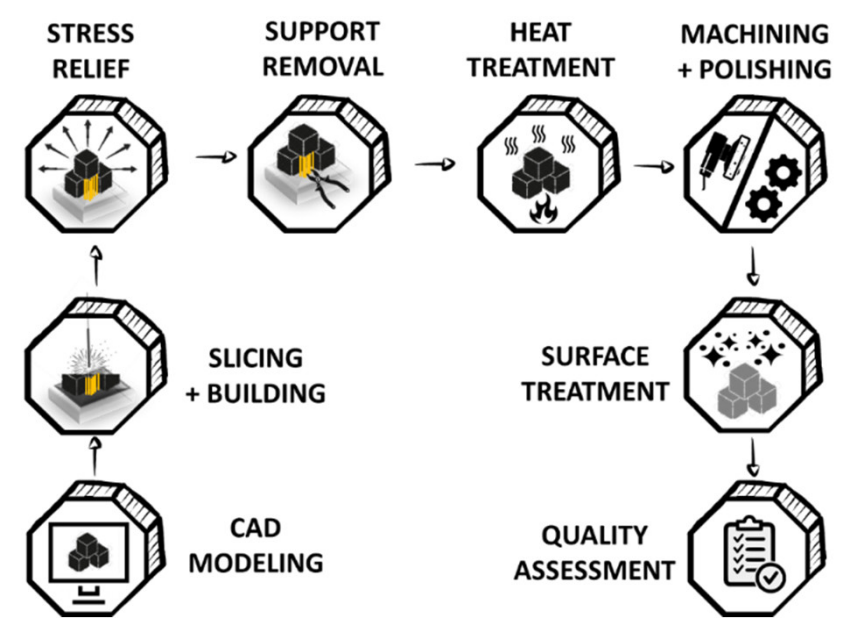

Figure 6. Schematics showing the post-processing workflow.

\subsection{Various AM Biomimicking Metal Implants-with Clinical Case Studies}

Undoubtedly, metal 3D printing is the best alternative for constructing load-bearing biomimicking implants that can perform on par with natural bone in elastic modulus, compressible and tensile strength, lattice arrangement, and pore size. They are extensively used in the current clinical setup, mostly due to their customizable nature and patient specificity, which, when coupled with the technical superiority of the processing technique, makes it the future of implantology. Metal additive manufacturing of biomimicking implants (as shown in Figure 7) is a decade-old technology, and one of the first reported instances of experimental implantation was performed in 2014 in a 71-year male patient suffering from grade 2 chondrosarcoma. The subject received a custom additively-manufactured titanium heel prosthesis with a smooth surface attaching to the bone tissue, provisions for suturing the implants onto the heel, and a micro-rough surface to promote tissue adhesion $[159,160]$. The sections below will substantiate the types of biomimicking implants and prostheses and their clinical status, processing technology. Different AM implants and types of processing, the material used are summarized in Table 4.

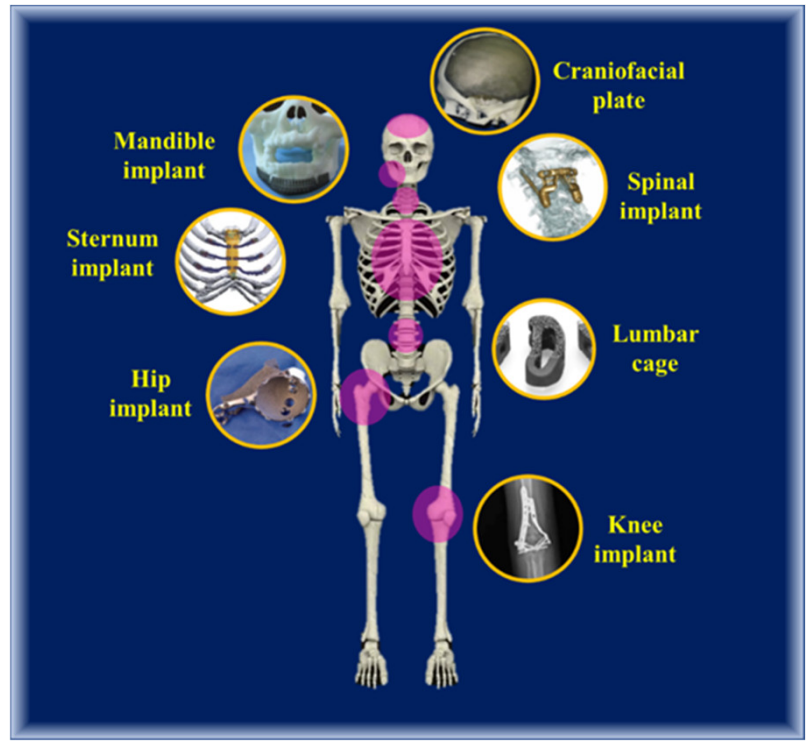

Figure 7. Craniofacial plate implant Ti-6Al-4V DMLS [161], mandibular implants [162], spinal [163] and sternum [164] implants, lumbar cage [165], hip [166], and knee implants [167]. Reprinted under copyright CCBY-NC-ND 4.0 license. 


\subsubsection{Cranioplasty Implants}

Cranioplasty is the surgical regimen that focuses on repairing skull bone defects that are either caused by accident or previous surgery. Titanium/its alloy as a mesh or dense metal, synthetic bone substitute in liquid form, or solid biomaterial made of metal or polymer is the most widely used clinical materials for the repairs [168]. One of the earliest known rapid prototyping of skull plates was in the early 1990s, where the skull defect was repaired using a stereolithographic printed acrylic model to custom-make a titanium implant to fit the patient's defect [169]. However, with the advent of metal 3D printing, efforts have been made to print porous skull implants directly using direct metal laser sintering (DMLS) [170]. Another interesting approach was demonstrated by Alida et al. in a 2008 study, where PHANToM 1.5 haptics were incorporated with electron beam melting (EBM) for automated custom printing of skull plates with $50 \%$ reduced time consumption [171]. Titanium used to be the favorite metal for prototyping, which Ti-6Al-4V gradually overtook due to its superior mechanical properties. A 2018 study by QichunRan et al. observed that selective laser melting (SLM) printed implants with a pore size of $700 \mu \mathrm{m}$ exhibited superior bone ingrowth, which points towards the advantage of AM in mimicking natural bone [172]. AM has found applications in designing, simulating, and manufacturing cranial implants. One of the best instances is demonstrated in a 2018 study by Antonio Marzola et al., where a 3D printed model of the defect helped surgeons carefully plan for the surgery to avoid skin flapping complications while an EBM processed Ti-6Al-4V skull implant was used to repair the defect [173].

\subsubsection{Vascular Stent}

A vascular stent is a mechanical structure secured inside a coronary artery to create a channel for the uninterrupted flow of blood. It is mainly used to treat coronary artery disease or peripheral artery diseases. Percutaneous coronary interventions, balloon angioplasty, and coronary balloon dilation are some clinical practices that make use of a vascular stent [174]. During the early phase of stent implantology, bare-metal stents (BMS), drug-eluting stents (DES), and bioresorbable stents (BRS) are some of the prevalent iterations [175]. Traditional manufacturing practices include photolithography-based etching, micro-EDM, electroforming, die-casting, and laser cutting [175]. Electrospinning has emerged as a novel processing technique for the vascular stent, but with its superior precision for millimeter thick stents, AM is one of the most preferred choices. Stereolithography (SL), selective laser sintering (SLS), and fused deposition modeling (FDM) are the preferred AM methods for stent construction. Demir and Barbara, in a 2017 study, had employed SLM for manufacturing a CoCr stent, which had demonstrated satisfactory mechanical properties and could be a suitable substitute for laser-based micro-cutting [176]. Nitinol is one of the preferred alloys for stent construction due to its superior pseudoelasticity, and it is made by combining varying weight percentages of Titanium and Nickel. A team of scientists from the Commonwealth Scientific and Industrial Research Organization (CSIRO) was the first to 3D print a Nitinol stent using SLM technology [177]. This 3D printed stent undergoes a phase transformation at sub-human body temperature for self-expansion, making it a smart biomaterial unheard of until then. However, 3D metal printing also exhibits certain design constraints, as observed by McGee et al. in a 2021 published study. The SLM-printed titanium stents need to be self-supporting, which creates a design constriction. It was eliminated using a hybrid approach of combining SLM with etching to create open cell designs [178].

\subsubsection{Bone Fixtures}

AM is widely used to construct bone implants, such as the knee, hip, clavicle, and cranium; however, their potential in custom printing complex fixtures is underexplored [179]. Three-dimensional printed guides for superior contouring were the initial products manufactured using AM, but recent advances in rapid prototyping enable 3D printing of the fixtures. The most commonly used fixtures are bone plates, screws, nails or rods, and wires 
to immobilize the bone segment that underwent fracture [180]. A 2016 study by Smith et al. describes the clinical use of SLM-printed Ti-6Al-4V extra low interstitial (ELI) bone plate to fix hallux valgus (bunion) deformities, which otherwise would depend on surgical interventions, such as osteotomy [181]. Bone screws are one of the load-bearing fixtures, and bioabsorbable screws are prone to breakage, as reported in several studies, thus demanding the need for metal screws $[182,183]$ In a recent study by Yu-Min et al., an SLM-printed bone screw using Ti-6Al-4V was implanted in a rabbit model to assess the feasibility of the interference screw fixation method. The screws were surface modified chemically using calcium phosphate to improve the bioactivity of the screw-bone interface [184]. Another customized intervention was reported by Ying Zhang et al., where a Ti-6Al-4V trabecular bone and connecting rods were printed using electron beam manufacturing technology for treating early-stage osteonecrosis in the femoral head [185]. A customized clinical intervention is very uncommon in bone pathophysiology and made possible only because of AM.

\subsubsection{Hip and Knee Implant}

The hip, knee, and ankles joints are the most load-bearing intersections in the human body. One of the major hurdles with knee or hip replacement surgery is that they could improve patient mobility; however, that necessarily does not improve the quality of life or eliminate the need for revision surgery, especially in young patients [186]. Several studies indicate that patient-specific implants could overcome many challenges in traditional hip and knee replacement approaches [187-189]. For example, in a 2012 study reported by Murr et al., open-cellular structures of Ti-6Al-4V and Co-29Cr-6Mo implants were printed using the EBM technique yielding a porous, monolithic, and patient-specific product with superior bone-ingrowth capabilities [190]. In a 2016 study by Arabnejad et al., a porous, titanium femoral stem 3D-printed using SLM exhibited reduced stress-shielding, attributed to the optimal relative density distribution resulting in natural bone-like mechanical properties [191]. Surface modifications are usually performed on traditional implants to improve the bioactivity of the bone-metal interphase. AM can incorporate micro resolution surface architectures during printing, which can partially or fully replace an additional surface treatment. Noel and colleagues had compared a Ti-6Al-4V hip stem component with proprietary AM Osteo Anchor architecture against plasma-sprayed Ti coating that is prevalently used. After implanting in animals, it was observed that proprietary AM Osteo Anchor architecture exhibited improved primary fixation and bone-ingrowth. Since hip and knee replacement is one of the widely performed implantations, the single-step, patient-specific, and mechanically superior implant manufacturing offered by AM reduces the need for revision surgery and further improves patient mobility compared to traditional practice.

\subsubsection{Sternum Implant}

Sternum repair is often performed after open-heart surgery [192]. However, total sternum replacement is an uncommon surgery, and no streamlined protocol exists clinically [193]. One of the earliest reported case studies of a sternum replacement surgery using AM was from a 2013 study by Turna et al. A female patient with metastatic breast carcinoma extended to sternum received a sandblasted SLS printed titanium sternum. In another 2016 study, a similar approach was adopted, where an additively-manufactured half sternum with three adjacent ribs was printed with costo-sternal joints, which mimicked natural movements [194]. In a 2018 publication by Anton et al., a 3D-printed titanium sternum was implanted in a 70-year-old female patient with a sternal tumor. Dislocation or migration is one of the risks associated with a surgery of this degree, and precise 3D printed surgical guides were used in pre-operative planning, which helped the surgeons plan the number and location of fixtures. This study presented a novel multidimensional approach for chest wall reconstruction, which could be advantageous, especially in traumatic repairs [164]. 


\subsubsection{Spinal Implant}

Spine implantation is a billion-dollar market with a lot of big players, such as Renishaw and Medtronic, involved. Additive manufacturing is the most preferred choice of manufacturing due to the reduced cost and patient-specificity [195]. Congenital or traumatic medical conditions, such as degenerative disc disease, herniated disc, spondylolisthesis, spinal stenosis, and osteoporosis, could result in spinal implantation to correct the intervertebral height of the patient [196]. Three-dimensional printing can be employed for pre-operative planning, screw guides, osteotomy guides, tumor repair, bio-tissue manufacturing, and education [197]. One of the reported applications of 3D printing in spinal implantation was of a 14-year-old girl with hemangioendothelioma. The patient received a custommade Ti-6Al-4V reconstruction cage for the T9 vertebral body, which accommodated the kyphoscoliotic nature. The study also reports that the patient had no complications and exhibited bone integration in the 6th-month follow-up [198]. In a 2016 study by Xu et al., a 12-year male patient with C2 Ewing sarcoma received an EBM-printed titanium alloy C2 self-stabilizing artificial vertebral body (SSAVB) with personalized wings. In the 12th follow-up, the patient had improved neurological function with a Japanese Orthopaedic Association (JOA) score of 16/17 alongside improved osteointegration [199]. Another clinical case study of a 3D-printed spinal implant was reported by Mobbs et al. in 2019, where a 34-year-old male patient with spondylosis caused by a congenital anomaly in L5/S1 of anterior lumbar interbody fusion (ALIF) received a DMLS printed Ti-6Al-4V corrective implant with angled holes. The design aspect of this implant favored an easy insertion with press-fit as per the report, and the patient did not suffer from any intra/postoperative complications with reduced radiculopathy pain and early osteointegration [200]. Unlike an over-the-shelf (OTS) implant, the custom printed spine implants were observed to mimic the natural function of the replaced bone, thereby inducing superior osteointegration and reduced inflammatory response [198,201].

\subsubsection{Mandibular Implant}

Mandibular implants are widely used to reconstruct the jaw due to diseases, such as osteonecrosis, inflammation, or cancer, or an accident. In addition, mandibular augmentation is a burgeoning cosmetic surgery that increases the demand for mandibular implants. The mandible has significant physiological functions, such as craniofacial development, mastication, breathing, and deglutition [202]. In traditional clinical practice, the reconstruction was performed using bone grafts obtained from the tibia, rib, and iliac crest [203]. However, this approach could not yield a perfect aesthetic fit. Three-dimensional metal printing is a perfect solution to construct a load-bearing implant with a good aesthetic fit. In addition, the patient satisfaction post-implantation was found to be significantly higher with 3D printed mandibular implants compared to conventional approaches, such as titanium reconstruction plates and autologous grafting. Furthermore, the facial symmetry can be restored, and AM mandibular implants offer maximum mouth opening and occlusal function compared to conventional approaches [204]. In the study by Yan et al., four patients with ameloblastoma and squamous cell carcinoma were recruited to receive a custom EBM-printed titanium mandibular implant. The test group had a mean operative time of $130 \mathrm{~min}$ and an average follow-up of 12 months, with normal maximum mouth opening ranging from 25 to $40 \mathrm{~mm}$. All patients had a satisfactory postoperative dental rehabilitation when considering criteria, such as speech, chewing pain, occlusal force, swallowing, or eating difficulty [204]. In another case study by Park et al. from 2020, a 53-year-old male patient suffering from osteoradionecrosis received an SLM-printed titanium implant with premounted dental fixtures. Here, the titanium mandible was not immediately operated on for dental prosthesis installation due to the risk of infection; however, the installation was performed after proper osseointegration of the mandible [205]. 


\subsubsection{Dental Screws and Prostheses}

Dental implantation is comparatively less complicated and the most prevalent implantation surgery with a wide scope for additive manufacturing [206]. The results can be easily analyzed, post-surgical complications can be identified at early stages, and any corrections can be implemented effortlessly compared to other implants. According to a 2019 review, nearly 1322 articles are published based on 3D-printed dental implants, pointing towards the scope of AM in dentistry. Most commonly used are titanium/alloys, nickel alloys, and cobalt-chromium; however, nickel alloys are sidelined in current clinical practice due to allergic reactions it triggers [207]. Milling was one of the conventional techniques used in $\mathrm{CoCr}$ dental prosthesis manufacturing; however, metal shrinking is a common shortcoming with this technique, which can be eliminated in 3D printing $[208,209]$. Several clinical references cite AM in endodontics, prosthodontics, maxillofacial surgery, periodontal surgery, orthodontics, and dental implantation [207]. In a study conducted at McGill University, Montreal, it was observed that SLM-printed removable partial dentures are more favorable than cast metal dentures from patient convenience and satisfaction standpoints. The higher mimicking resolution offered by AM helps in improved comfort, mastication, speech, and oral hygiene [210]. A 2016 study by Samy et al., with 3-year long patient follow-up, elucidates the performance of DMLS-printed Ti-6Al-4V implants. In this study, 86 volunteers received a total of 110 implants with the same number of prosthetic restorations using single crowns, and at the end of the third year, there was a $94.5 \%$ implant survival rate and $94.3 \%$ crown success rate. The researchers concluded that 'AM is a successful clinical option for the rehabilitation of single-tooth gaps in both jaws [211].' Dental prostheses were often reconstructed using a metal-ceramic or all-ceramic composition. However, ceramic is prone to chipping or fracture, which could comprise the prosthesis and, therefore, AM single crowns or fixed-dental prosthesis (FDP) made from $\mathrm{Co}-\mathrm{Cr}$ or titanium alloys are widely preferred. Hesse et al., in their 2020 review paper, identify that SLS is widely preferred for CoCr printing, while EBM is the preferred method for the construction of titanium dental prosthesis [212]. However, the same review criticizes the lack of standardization and regulation in the AM of dental prostheses, which shall be attributed to the early hiccups in this technology.

\subsubsection{Bone Scaffold}

A bone scaffold is identified as a three-dimensional matrix made of a biocompatible material that can mimic the working of actual bone, i.e., attachment and proliferation of osteogenic cells [213]. Ghassemi and colleagues, in their 2018 review paper, identified a few criteria for bone scaffolds, of which the mechanical strength, especially during the amelioration phase and architecture mimicking capability, are two important parameters that emphasize the need for a better metal scaffold [213,214]. However, AM had already solved the mimicking of complex bone architecture to an extent with its different lattice structure adaptations and is on the verge of perfecting the natural bone structure $[215,216]$. One of the early studies of the natural bone mimicking scaffold was reported by Wu et al. in 2008, where hot isostatic pressing was employed to 3D print NiTi and Ti scaffolds with improved super hydrophilicity and hydroxyapatite deposition. One of the recent clinical studies on a live model was reported in 2020 by Crovace et al., in which an EBM-printed Ti-6Al-4V porous scaffold was implanted in a sheep model. The study elucidated the scope of 3D printing in repairing large bone defects. The implant had the optimal load-bearing capability while retaining its functional capabilities [217]. The adaptation of AM metallic bone scaffolds is yet to be clinically translated; however, it shows a promising future in large bone defect repairs. 
Table 4. Summary of AM implantations, type of processing, the material used, and additional clinical citations.

\begin{tabular}{|c|c|c|c|c|c|c|c|}
\hline S.No & $\begin{array}{l}\text { Type of } \\
\text { Implant }\end{array}$ & $\begin{array}{l}\text { Purpose of } \\
\text { Implant }\end{array}$ & Process & Material & Details of Case Study & $\begin{array}{l}\text { Parameters/ } \\
\text { Specifications }\end{array}$ & Reference \\
\hline \multirow{5}{*}{1.} & \multirow{5}{*}{$\begin{array}{l}\text { CRANIO- } \\
\text { FACIAL }\end{array}$} & \multirow{5}{*}{$\begin{array}{l}\text { To protect the } \\
\text { brain and } \\
\text { alleviate } \\
\text { psychological } \\
\text { affliction caused } \\
\text { by the bone } \\
\text { defect and } \\
\text { restore the } \\
\text { patient's } \\
\text { appearance and } \\
\text { psychological } \\
\text { stability. }\end{array}$} & EBM & Ti6Al4V ELI & $\begin{array}{l}\text { A 38-year-old patient } \\
\text { was referred to a } \\
\text { craniofacial surgeon } \\
\text { with a large cranial } \\
\text { defect in the left } \\
\text { parieto-temporal area. } \\
\text { Cranial reconstruction } \\
\text { surgery was performed. }\end{array}$ & $\begin{array}{c}\text { Powder } \\
\text { size-50-100 } \mu \mathrm{m}, \\
\text { Implant } \\
\text { thickness-1.25 mm, } \\
\text { Pore size } \\
\text { diameter-700 } \mu \mathrm{m} \\
\text { Strut size- } 800 \mu \mathrm{m}\end{array}$ & [218] \\
\hline & & & DMLS & Ti6Al4V ELI & $\begin{array}{l}\text { A 22-year-old male } \\
\text { patient had a large } \\
\text { post-trauma defect in } \\
\text { the right frontal bone. } \\
\text { Reconstruction of the } \\
\text { cranial defect was } \\
\text { required to restore the } \\
\text { structural integrity of } \\
\text { the skull and the } \\
\text { patient's facial } \\
\text { aesthetics. }\end{array}$ & $\begin{array}{l}\text { Cranial replacement } \\
\text { area- }-12.5 \times 8.4 \mathrm{~cm}^{2}\end{array}$ & [219] \\
\hline & & & DMLS & Ti6Al4V ELI & $\begin{array}{l}\text { A 28-year-old male } \\
\text { patient had a large } \\
\text { post-trauma defect in } \\
\text { the right frontal bone. } \\
\text { Reconstruction of the } \\
\text { cranial defect was } \\
\text { required to restore the } \\
\text { structural integrity of } \\
\text { the skull and the } \\
\text { patient's facial } \\
\text { aesthetics. }\end{array}$ & $\begin{array}{l}\text { Bone defect } \\
\text { area-13.5 } \times 9.4 \mathrm{~cm}^{2}, \\
\text { Total weight of } \\
\text { prosthesis- } 82 \mathrm{~g}, \\
\text { Thickness-2-3 mm }\end{array}$ & [220] \\
\hline & & & EBM & Ti6Al4V ELI & $\begin{array}{l}\text { A 7-year-old girl had a } \\
\text { huge frontonasal bone } \\
\text { defect with consequent } \\
\text { hypertelorism. } \\
\text { Reconstruction of the } \\
\text { cranial defect was } \\
\text { required to restore the } \\
\text { structural integrity of } \\
\text { the skull and the } \\
\text { patient's facial } \\
\text { aesthetics. }\end{array}$ & $\begin{array}{l}\text { Powder } \\
\text { size-45-100 } \mu \mathrm{m} \text {, } \\
\text { Implant } \\
\text { weight-12.20 g, } \\
\text { Implant } \\
\text { thickness-7 mm, } \\
\text { Pore size } \\
\text { diameter-2mm }\end{array}$ & [221] \\
\hline & & & EBM & Ti6Al4V & $\begin{array}{l}\text { Three female patients } \\
\text { (tumor-one patient, } \\
\text { trauma-two patients) } \\
\text { were chosen for the } \\
\text { study. Reconstruction of } \\
\text { the cranial defect was } \\
\text { required to restore the } \\
\text { structural integrity of } \\
\text { the skull and the } \\
\text { patient's facial } \\
\text { aesthetics. }\end{array}$ & $\begin{array}{l}\text { Patient } 1 \text { defect } \\
\text { size-12 } 12 \times 14 \mathrm{~cm}^{2}, \\
\text { Patient } 2 \text { defect } \\
\text { size-14 } \times 11 \mathrm{~cm}^{2}, \\
\text { Patient } 3 \text { defect } \\
\text { size-15 } \times 15 \mathrm{~cm}^{2}\end{array}$ & [222] \\
\hline
\end{tabular}


Table 4. Cont.

\begin{tabular}{|c|c|c|c|c|c|c|c|}
\hline S.No & $\begin{array}{l}\text { Type of } \\
\text { Implant }\end{array}$ & $\begin{array}{l}\text { Purpose of } \\
\text { Implant }\end{array}$ & Process & Material & Details of Case Study & $\begin{array}{c}\text { Parameters/ } \\
\text { Specifications }\end{array}$ & Reference \\
\hline & & & EBM & Ti6Al4V & $\begin{array}{l}\text { A 27-year-old woman } \\
\text { with a wide cranial vault } \\
\text { lacuna in the upper part } \\
\text { of the skull and slightly } \\
\text { crossing the sagittal } \\
\text { plane underwent } \\
\text { reconstruction surgery } \\
\text { to restore the shape and } \\
\text { function of the cranium. }\end{array}$ & - & [173] \\
\hline \multirow{5}{*}{2.} & \multirow{5}{*}{$\begin{array}{l}\text { MAXILL- } \\
\text { OFACIAL }\end{array}$} & \multirow{5}{*}{$\begin{array}{l}\text { To achieve } \\
\text { correct shape of } \\
\text { orbital wall or } \\
\text { jaw and } \\
\text { reconstruction } \\
\text { followed by } \\
\text { resection of the } \\
\text { tumor region. }\end{array}$} & DMLS & Ti6Al4V ELI & $\begin{array}{c}\text { The patient was a } \\
\text { 67-year-old male who } \\
\text { had been in a severe } \\
\text { accident. Reconstructive } \\
\text { treatment was } \\
\text { performed to achieve } \\
\text { anatomically correct } \\
\text { shape of the orbital wall } \\
\text { and appearance of the } \\
\text { eye symmetry. }\end{array}$ & $\begin{array}{c}\text { Thickness-0.4 mm, } \\
\text { Hole size-3 mm, } \\
\text { Hole size } \\
\text { (screw) }-2 \mathrm{~mm}\end{array}$ & [223] \\
\hline & & & EBM & Ti6Al4V ELI & $\begin{array}{l}\text { Tumor treatment-The } \\
\text { mandible section with } \\
\text { the tumor on the } \\
\text { patient's left side was } \\
\text { removed and replaced } \\
\text { by mirroring the healthy } \\
\text { right mandible. }\end{array}$ & $\begin{array}{c}\text { Powder } \\
\text { size-50-100 } \mu \mathrm{m}, \\
\text { Offset } \\
\text { thickness-2 mm, } \\
\text { Mesh size- } 0.4 \mathrm{~mm} \text {, }\end{array}$ & [224] \\
\hline & & & EBM & Ti6Al4V ELI & $\begin{array}{l}\text { A 40-year-old patient } \\
\text { underwent a } \\
\text { multilocular radiolucent } \\
\text { lesion on the right } \\
\text { posterior mandible. } \\
\text { Reconstruction of the } \\
\text { discontinuous mandible } \\
\text { defect was performed. }\end{array}$ & - & [225] \\
\hline & & & SLM & $\begin{array}{l}\text { Ti6Al4V- } \\
\text { Grade } \\
2\end{array}$ & $\begin{array}{l}\text { The 50-year-old patient } \\
\text { presented maxillary } \\
\text { epidermoid carcinoma } \\
\text { history with nasal } \\
\text { affection addressed two } \\
\text { years ago by a total } \\
\text { maxillectomy and total } \\
\text { nasal amputation. Nasal } \\
\text { reconstruction was } \\
\text { performed. }\end{array}$ & $\begin{array}{l}\text { Thickness- } \\
0.4-0.7 \mathrm{~mm} \text {, } \\
\text { Pore dimension- } \\
860-1500 \mu \mathrm{m}\end{array}$ & [226] \\
\hline & & & SLM & cT4N1M0 & $\begin{array}{l}\text { A 53-year-old male } \\
\text { suffered } \\
\text { osteoradionecrosis due } \\
\text { to the radiation therapy } \\
\text { after squamous cell } \\
\text { carcinoma resection of } \\
\text { attached gingiva in the } \\
\text { left mandible. The } \\
\text { reconstruction plate } \\
\text { was fixed. }\end{array}$ & - & [205] \\
\hline
\end{tabular}


Table 4. Cont.

\begin{tabular}{|c|c|c|c|c|c|c|c|}
\hline S.No & $\begin{array}{l}\text { Type of } \\
\text { Implant }\end{array}$ & $\begin{array}{l}\text { Purpose of } \\
\text { Implant }\end{array}$ & Process & Material & Details of Case Study & $\begin{array}{c}\text { Parameters/ } \\
\text { Specifications }\end{array}$ & Reference \\
\hline \multirow{5}{*}{3.} & \multirow{5}{*}{$\begin{array}{l}\text { DENTAL } \\
\text { IMPLANT }\end{array}$} & \multirow{5}{*}{$\begin{array}{l}\text { To restore the } \\
\text { function of the } \\
\text { tooth or jaw } \\
\text { affected due to } \\
\text { tumors or } \\
\text { accidents. }\end{array}$} & SLS & Ti6Al4V & $\begin{array}{l}16 \text { patients with possible } \\
\text { dental repair were } \\
\text { voluntarily recruited for } \\
\text { the clinical study. }\end{array}$ & $\begin{array}{c}\text { Powder } \\
\text { size- }-25-45 \mu \mathrm{m}, \\
\text { Diameter-2.7 mm, } \\
\text { Length-10 mm }\end{array}$ & [227] \\
\hline & & & DLMS & Ti6Al4V & $\begin{array}{c}15 \text { patients, } 8 \text { males and } \\
7 \text { females (age } 39-55), \\
\text { were selected for the } \\
\text { study based on the } \\
\text { possibility of a } \\
\text { dental repair. }\end{array}$ & $\begin{array}{c}\text { Powder } \\
\text { size-25-45 } \mu \mathrm{m}, \\
\text { Cylindrical implant: } \\
\text { alveolar } \\
\text { apex-3-5 mm }\end{array}$ & [228] \\
\hline & & & DMLS & Ti6Al4V & $\begin{array}{l}\text { A 17-year-old male } \\
\text { patient who sustained } \\
\text { an injury to the anterior } \\
\text { maxillary region leading } \\
\text { to loss of upper front } \\
\text { teeth along with bone } \\
\text { was presented in this } \\
\text { case study. }\end{array}$ & - & [229] \\
\hline & & & DMLS & Ti6Al4V & $\begin{array}{c}44 \text { males, } 38 \text { females, age } \\
\text { range } 26-67 \text { years were } \\
\text { voluntarily recruited for } \\
\text { the study. }\end{array}$ & $\begin{array}{l}\text { Laser wavelength- } \\
1054 \mathrm{~nm} \text {, Laser } \\
\text { power-200 W, } \\
\text { Scanning } \\
\text { rate-7 m/s, Laser } \\
\text { spot size-0.1 mm, } \\
\text { Powder } \\
\text { size-25-45 } \mu \mathrm{m}\end{array}$ & [211] \\
\hline & & & DMLS & Ti6Al4V & $\begin{array}{l}39 \text { males and } 31 \text { females, } \\
\text { aged } 62-79 \text { years with } \\
\text { dental repair were } \\
\text { voluntarily enrolled for } \\
\text { the study. }\end{array}$ & $\begin{array}{l}\text { Laser wavelength- } \\
1070 \mathrm{~nm}, \\
\text { Laser power-50/W }\end{array}$ & [230] \\
\hline \multirow{3}{*}{4.} & \multirow{3}{*}{$\begin{array}{l}\text { SPINAL } \\
\text { IMPLANT }\end{array}$} & \multirow{3}{*}{$\begin{array}{l}\text { Degenerative } \\
\text { diseases, } \\
\text { fractures, and } \\
\text { other disorders } \\
\text { can lead to the } \\
\text { functional loss of } \\
\text { the spine. Spinal } \\
\text { fixation or spinal } \\
\text { reconstruction } \\
\text { can retain the } \\
\text { function of the } \\
\text { spine after the } \\
\text { resection of the } \\
\text { affected area }\end{array}$} & DMLS & $\begin{array}{l}\text { Ti6Al4V } \\
\text { Grade } 5\end{array}$ & $\begin{array}{l}\text { A 45-year-old man } \\
\text { presented with neck and } \\
\text { left arm pain combined } \\
\text { with shoulder weakness. } \\
\text { Imaging revealed } \\
\text { significant destruction of } \\
\text { the C3-C5 vertebrae, and } \\
\text { chordoma diagnosis was } \\
\text { confirmed by biopsy. }\end{array}$ & $\begin{array}{l}\text { Laser power-200 W, } \\
\text { Laser spot } \\
\text { diameter-55 } \mu \mathrm{m} \text {, } \\
\text { Layer } \\
\text { thickness-20-40 } \mu \mathrm{m}\end{array}$ & [231] \\
\hline & & & \multirow[t]{2}{*}{ DMLS } & \multirow{2}{*}{ Ti6Al4V ELI } & $\begin{array}{l}\text { A 16-year-old boy had a } \\
\text { severe kyphotic } \\
\text { deformity of the thoracic } \\
\text { spine resulting from } \\
\text { neurofibromatosis } \\
\text { type I. }\end{array}$ & $\begin{array}{c}\text { Pore } \\
\text { size }-500-600 \mu \mathrm{m}\end{array}$ & \multirow[t]{2}{*}{ [232] } \\
\hline & & & & & $\begin{array}{l}\text { A 63-year-old woman } \\
\text { with progressive } \\
\text { paralysis due to a severe } \\
\text { cervicothoracic } \\
\text { dissociation. }\end{array}$ & $\begin{array}{l}\text { Implant } \\
\text { width-10 mm, } \\
\text { Depth-5 mm, } \\
\text { Height- } 8 \mathrm{~mm}\end{array}$ & \\
\hline
\end{tabular}


Table 4. Cont

\begin{tabular}{|c|c|c|c|c|c|c|c|}
\hline S.No & $\begin{array}{l}\text { Type of } \\
\text { Implant }\end{array}$ & $\begin{array}{c}\text { Purpose of } \\
\text { Implant }\end{array}$ & Process & Material & Details of Case Study & $\begin{array}{c}\text { Parameters/ } \\
\text { Specifications }\end{array}$ & Reference \\
\hline & & & EBM & Ti6Al4V & $\begin{array}{l}9 \text { patients ( } 2 \text { males and } 7 \\
\text { females) were included } \\
\text { in the study with a mean } \\
\text { age of } 31.4 \text { years ( } 12 \text { to } \\
59 \text { years) for } \\
\text { reconstruction following } \\
\text { resection of the primary } \\
\text { tumors of the upper } \\
\text { cervical spine. }\end{array}$ & $\begin{array}{c}\text { Powder } \\
\text { size- }-45-100 \mu \mathrm{m}\end{array}$ & [233] \\
\hline & & & FDM & Ti6Al4V & $\begin{array}{l}\text { A 12-year-old patient } \\
\text { suffering from } \\
\text { congenital scoliosis due } \\
\text { to an L1 hemivertebra } \\
\text { underwent a } \\
\text { corpectomy and } \\
\text { stabilization surgery } \\
\text { from Th9 to L4. }\end{array}$ & - & [234] \\
\hline \multirow{4}{*}{5.} & \multirow{4}{*}{$\begin{array}{l}\text { FOOT/HAND } \\
\text { IMPLANT }\end{array}$} & \multirow{4}{*}{$\begin{array}{l}\text { Foot or hand } \\
\text { implants are } \\
\text { used for } \\
\text { reconstructing } \\
\text { the defective/ } \\
\text { fracture/tumor- } \\
\text { affected } \\
\text { bone. }\end{array}$} & EBM & Ti6Al4V & $\begin{array}{c}\text { A 40-year-old man } \\
\text { presented with } \\
\text { two-week-long } \\
\text { paresthesia in his right } \\
\text { hand and limited } \\
\text { forearm rotation due to } \\
\text { dislocation of the radial } \\
\text { head attributed to a } \\
\text { traumatic injury during } \\
\text { childhood. }\end{array}$ & $\begin{array}{l}\text { Length of the } \\
\text { implant }-15 \mathrm{~cm} \text {, } \\
\text { Weight }-67 \mathrm{~g} \text {, } \\
\text { Pore size-700 and } \\
1500 \mu \mathrm{m}\end{array}$ & [235] \\
\hline & & & EBM & Ti6Al4V ELI & $\begin{array}{l}\text { A 23-year-old soldier } \\
\text { was diagnosed with a } \\
\text { calcaneal desmoplastic } \\
\text { fibroma. Reconstruction } \\
\text { surgery was performed } \\
\text { for the bone tumor } \\
\text { calcaneus. }\end{array}$ & $\begin{array}{l}\text { Length of the } \\
\text { implant-63.5 mm, } \\
\text { Height-43.2 mm, } \\
\text { Weight-104 g }\end{array}$ & [236] \\
\hline & & & EBM & Ti6Al4V & $\begin{array}{l}\text { A 71-year-old man } \\
\text { presented with a } \\
\text { destructive and highly } \\
\text { metabolic lesion in the } \\
\text { right calcaneus. A total } \\
\text { calcanectomy was } \\
\text { performed, and the } \\
\text { defect was reconstructed } \\
\text { with 3D printed } \\
\text { titanium calcaneal } \\
\text { prosthesis. }\end{array}$ & $\begin{array}{c}\text { Implant } \\
\text { weight-280 g }\end{array}$ & [159] \\
\hline & & & EBM & Ti6Al4V ELI & $\begin{array}{l}3 \text { patients (one male and } \\
\text { two females) had } \\
\text { undergone surgery for } \\
\text { oncological diagnosis, } \\
\text { and reconstruction } \\
\text { surgery was performed. }\end{array}$ & - & [237] \\
\hline
\end{tabular}


Table 4. Cont.

\begin{tabular}{|c|c|c|c|c|c|c|c|}
\hline S.No & $\begin{array}{l}\text { Type of } \\
\text { Implant }\end{array}$ & $\begin{array}{c}\text { Purpose of } \\
\text { Implant }\end{array}$ & Process & Material & Details of Case Study & $\begin{array}{c}\text { Parameters/ } \\
\text { Specifications }\end{array}$ & Reference \\
\hline \multirow{5}{*}{6.} & \multirow{5}{*}{$\begin{array}{l}\text { PELVIC } \\
\text { IMPLANT }\end{array}$} & \multirow{5}{*}{$\begin{array}{l}\text { Pelvic implants } \\
\text { provide support } \\
\text { or replace the } \\
\text { weaker bones } \\
\text { due to arthritis, } \\
\text { tumor, or } \\
\text { fracture. }\end{array}$} & SLM & Ti6Al4V & $\begin{array}{l}\text { A 65-year-old man } \\
\text { presented with } \\
\text { expansile osteolytic } \\
\text { destruction at the } \\
\text { anterior column of the } \\
\text { left acetabulum. Pelvic } \\
\text { tumor resection and } \\
\text { prosthetic reconstruction } \\
\text { of the bone defect were } \\
\text { planned in the study. }\end{array}$ & - & [166] \\
\hline & & & EBM & Ti6Al4V ELI & $\begin{array}{l}7 \text { patients ( } 3 \text { males and } 4 \\
\text { females) were chosen for } \\
\text { the study based on } \\
\text { existing pelvic/hip } \\
\text { morbidity. Pelvic } \\
\text { reconstruction was } \\
\text { performed. }\end{array}$ & - & [237] \\
\hline & & & EBM & Ti6Al4V & $\begin{array}{l}13 \text { patients were chosen } \\
\text { for the study, of which } 3 \\
\text { patients had total hip } \\
\text { replacement surgery, } \\
\text { and } 4 \text { patients had } \\
\text { pelvic resection surgery. }\end{array}$ & - & [238] \\
\hline & & & EBM & Ti6Al4V & $\begin{array}{l}\text { A total of } 35 \text { patients (20 } \\
\text { males and } 15 \text { females) } \\
\text { underwent resection of } \\
\text { pelvic tumor and } \\
\text { reconstruction using 3D } \\
\text { printed endoprostheses. }\end{array}$ & - & [239] \\
\hline & & & EBM & Ti6Al4V & $\begin{array}{l}30 \text { patients were } \\
\text { involved in the study for } \\
\text { trabecular bone } \\
\text { reconstruction for early } \\
\text { osteonecrosis of the } \\
\text { femoral head. }\end{array}$ & $\begin{array}{c}\text { Power of } \\
\text { E-beam-3000 W, } \\
\text { Diameter of electron } \\
\text { beam-180 } \mu \mathrm{m}, \\
\text { Melting speed-55 } \\
\text { to } 80 \mathrm{~cm}^{3} / \mathrm{h} \text {, Degree } \\
\text { of vacuum work } \\
\text { area }<1 \times 10^{-4} \mathrm{mbar}\end{array}$ & [185] \\
\hline \multirow[t]{2}{*}{7.} & \multirow[t]{2}{*}{$\begin{array}{l}\text { STERNUM } \\
\text { IMPLANT }\end{array}$} & \multirow{2}{*}{$\begin{array}{c}\text { Sternum } \\
\text { implants protect } \\
\text { the heart, lungs, } \\
\text { and chest blood } \\
\text { vessels in people } \\
\text { with a } \\
\text { compromised } \\
\text { sternum. The } \\
\text { tumor-affected } \\
\text { sternum can also } \\
\text { be reconstructed } \\
\text { using sternum } \\
\text { implants. }\end{array}$} & EBM & Ti6Al4V & $\begin{array}{l}\text { A 57-year-old man } \\
\text { suffered from minor } \\
\text { thoracic trauma because } \\
\text { of prolonged chest pain } \\
\text { and chest wall tumor in } \\
\text { the chondrocostal } \\
\text { junction. A segment of } \\
\text { the sternum was } \\
\text { replaced to restore the } \\
\text { function. }\end{array}$ & $\begin{array}{c}\text { Implant size-147.36 } \\
\times 180.14 \times \\
128.30 \mathrm{~mm}^{3}\end{array}$ & [194] \\
\hline & & & DMLS & Ti6Al4V & $\begin{array}{l}\text { A 70-year-old woman } \\
\text { was affected by the } \\
\text { sternal tumor and } \\
\text { subtotal sternotomy. } \\
\text { Resection of the sternal } \\
\text { body with the adjacent } \\
\text { sternocostal cartilage } \\
\text { was performed. }\end{array}$ & $\begin{array}{l}\text { Weight of the } \\
\text { implant-53.5 g, } \\
\text { Size of the } \\
\text { implant-170 } \times 60 \\
\times 105 \mathrm{~mm}\end{array}$ & [164] \\
\hline
\end{tabular}


Table 4. Cont.

\begin{tabular}{|c|c|c|c|c|c|c|c|}
\hline S.No & $\begin{array}{l}\text { Type of } \\
\text { Implant }\end{array}$ & $\begin{array}{c}\text { Purpose of } \\
\text { Implant }\end{array}$ & Process & Material & Details of Case Study & $\begin{array}{c}\text { Parameters/ } \\
\text { Specifications }\end{array}$ & Reference \\
\hline & & & EBM & Ti6Al4V & $\begin{array}{l}\text { A 19-year-old woman } \\
\text { presented with anterior } \\
\text { chest wall instability and } \\
\text { paradoxical movement } \\
\text { with respiration. } \\
\text { Reconstruction after } \\
\text { anterior chest wall } \\
\text { resection was } \\
\text { performed. }\end{array}$ & T & [240] \\
\hline & & & SLM & Ti MG 1 & $\begin{array}{l}\text { A } 70 \text {-year-old male, with } \\
\text { a right anterior pectoral } \\
\text { mass approximately } 10 \\
\text { by } 9 \mathrm{~cm} \text { was presented } \\
\text { in the study for chest } \\
\text { wall resection following } \\
\text { wide local excision for } \\
\text { bone tumor. }\end{array}$ & - & [241] \\
\hline & & & SLM & Ti6Al4V ELI & $\begin{array}{l}\text { A 62-year-old female } \\
\text { was presented with a } \\
\text { mass located on the } \\
\text { chest wall associated } \\
\text { with foul smelly } \\
\text { drainage. } \\
\text { Reconstruction after } \\
\text { chest wall resection was } \\
\text { performed. }\end{array}$ & $\begin{array}{c}\text { The thickness of the } \\
\text { implant-2-3 mm, } \\
\text { Weight-160 g }\end{array}$ & [242] \\
\hline
\end{tabular}

\section{Future Scope and Challenges}

Personalized medicine is expected to be the next big revolution in the medical industry, and additive manufacturing has the best potential to keep up with the expectation of personalized implantation. The degree of freedom, precision in designing, and smart material integration are some of the salient features of AM. The versatility of materials employed for 3D printing makes it one of the major biomaterial or implant manufacturing processes. The advancement in computation and electronics enabled the democratization of 3D bioprinters, allowing more people to get hold of 3D printing equipment, which would considerably reduce the cost of AM of implants and crank up the technological advancements [243]. In the current generation of 3D printing, only bioinert or bioactive implants have been experimented with clinically; however, the next-generation AM focuses on bio 3D printing tissues and organs, which could be a game-changer in the medical industry.

Even though the future of AM looks promising, a few challenges need to be addressed before fully relying on AM. Certainly, the biomimetics of implants are improved compared to the conventional approach; however, this technology is still in its incubation phase. A few technological challenges include microstructural anisotropy, inferior mechanical properties due to void formation, stair-stepping affecting the external surface features, and limitation in scaling up at an industrial scale. Even the Food and Drug Administration (FDA) is still working on norms and regulations for making AM a safe clinical practice [244].

Author Contributions: Conceptualization, K.G.P. and G.M.; writing A.A.R., P.H., R.W., A.G., R.S.E., review and editing, A.K.J. and G.M.; supervision, K.G.P. and G.M.; manuscript administration, K.G.P. All authors have read and agreed to the published version of the manuscript.

Funding: Council of Industrial and Scientific Research (No.22(0803)/19/EMR II), Department of Science and Technology (DST/INT/SWD/VR/P15/2019) and European Regional Development Grant (ASTRA6-6).

Institutional Review Board Statement: Not applicable. 
Informed Consent Statement: Not applicable.

Data Availability Statement: Not applicable.

Acknowledgments: The authors are grateful to VIT, Vellore for the facility and support provided, and also to the Council of Industrial and Scientific Research (No.22(0803)/19/EMR II), the Government of India, for funding author Ansheed Raheem, as a Junior Research Fellow and Department of Science and Technology (DST/INT/SWD/VR/P15/2019), for funding author Pearlin Hameed as a Senior Research Fellow. Konda Gokuldoss Prashanth acknowledges the European Regional Development Grant (ASTRA6-6).

Conflicts of Interest: The authors declare no conflict of interest.

\section{References}

1. Aziz, M.S.; El Sherif, A.Y. Biomimicry as an approach for bio-inspired structure with the aid of computation. Alex. Eng. J. 2016, 55, 707-714. [CrossRef]

2. Hwang, J.; Jeong, Y.; Park, J.M.; Lee, K.H.; Hong, J.W.; Choi, J. Biomimetics: Forecasting the future of science, engineering, and medicine. Int. J. Nanomed. 2015, 10, 5701-5713. [CrossRef]

3. Peng, T.; Kellens, K.; Tang, R.; Chen, C.; Chen, G. Sustainability of additive manufacturing: An overview on its energy demand and environmental impact. Addit. Manuf. 2018, 21, 694-704. [CrossRef]

4. Zhakeyev, A.; Wang, P.; Zhang, L.; Shu, W.; Wang, H.; Xuan, J. Additive Manufacturing: Unlocking the Evolution of Energy Materials. Adv. Sci. 2017, 4, 1700187. [CrossRef] [PubMed]

5. Stone, R.B.; Mcadams, D.A. Translating terms of the functional basis into biologically meaningful keywords. In Proceedings of the ASME 2008 International Design Engineering Technical Conference \& Computers and Information in Engineering Conference, New York, NY, USA, 3-6 August 2008; pp. 1-12.

6. Li, Y.-C.E. Sustainable Biomass Materials for Biomedical Applications. ACS Biomater. Sci. Eng. 2019, 5, 2079-2092. [CrossRef]

7. Ruban, W.; Vijayakumar, V.; Dhanabal, P.; Pridhar, T. Effective process parameters in selective laser sintering. Int. J. Rapid Manuf. 2014, 4, 148. [CrossRef]

8. Prashanth, K.G.; Löber, L.; Klauss, H.-J.; Kühn, U.; Eckert, J. Characterization of 316L Steel Cellular Dodecahedron Structures Produced by Selective Laser Melting. Technologies 2016, 4, 34. [CrossRef]

9. Olakanmi, E.O.; Cochrane, R.; Dalgarno, K. A review on selective laser sintering/melting (SLS/SLM) of aluminium alloy powders: Processing, microstructure, and properties. Prog. Mater. Sci. 2015, 74, 401-477. [CrossRef]

10. Srinivasan, R.; Ruban, W.; Deepanraj, A.; Bhuvanesh, R.; Bhuvanesh, T. Effect on infill density on mechanical properties of PETG part fabricated by fused deposition modelling. Mater. Today Proc. 2020, 27, 1838-1842. [CrossRef]

11. Prashanth, K.G.; Scudino, S.; Chaubey, A.K.; Löber, L.; Wang, P.; Attar, H.; Schimansky, F.P.; Pyczak, F.; Eckert, J. Processing of Al-12Si-TNM composites by selective laser melting and evaluation of compressive and wear properties. J. Mater. Res. 2016, 31, 55-65. [CrossRef]

12. Prashanth, K.; Scudino, S.; Eckert, J. Defining the tensile properties of Al-12Si parts produced by selective laser melting. Acta Mater. 2017, 126, 25-35. [CrossRef]

13. Prashanth, K.; Scudino, S.; Klauss, H.; Surreddi, K.; Löber, L.; Wang, Z.; Chaubey, A.; Kühn, U.; Eckert, J. Microstructure and mechanical properties of Al-12Si produced by selective laser melting: Effect of heat treatment. Mater. Sci. Eng. A 2014, 590, 153-160. [CrossRef]

14. Kellens, K.; Baumers, M.; Gutowski, T.G.; Flanagan, W.; Lifset, R.; Duflou, J. Environmental Dimensions of Additive Manufacturing: Mapping Application Domains and Their Environmental Implications. J. Ind. Ecol. 2017, 21, S49-S68. [CrossRef]

15. Gokuldoss, P.K.; Kolla, S.; Eckert, J. Additive Manufacturing Processes: Selective Laser Melting, Electron Beam Melting and Binder Jetting-Selection Guidelines. Materials 2017, 10, 672. [CrossRef]

16. Scudino, S.; Unterdörfer, C.; Prashanth, K.; Attar, H.; Ellendt, N.; Uhlenwinkel, V.; Eckert, J. Additive manufacturing of Cu-10Sn bronze. Mater. Lett. 2015, 156, 202-204. [CrossRef]

17. Prashanth, K.; Damodaram, R.; Maity, T.; Wang, P.; Eckert, J. Friction welding of selective laser melted Ti6Al4V parts. Mater. Sci. Eng. A 2017, 704, 66-71. [CrossRef]

18. Gokuldoss Prashanth, K.; Scudino, S.; Eckert, J. Tensile Properties of Al-12Si Fabricated via Selective Laser Melting (SLM) at Different Temperatures. Technologies 2016, 4, 38. [CrossRef]

19. Prashanth, K.G.; Scudino, S.; Chatterjee, R.P.; Salman, O.O.; Eckert, J. Additive Manufacturing: Reproducibility of Metallic Parts. Technologies 2017, 5, 8. [CrossRef]

20. Salman, O.; Brenne, F.; Niendorf, T.; Eckert, J.; Prashanth, K.; He, T.; Scudino, S. Impact of the scanning strategy on the mechanical behavior of 316L steel synthesized by selective laser melting. J. Manuf. Process. 2019, 45, 255-261. [CrossRef]

21. Xi, L.X.; Zhang, H.; Wang, P.; Li, H.C.; Prashanth, K.G.; Lin, K.J.; Kaban, I.; Gu, D.D. Comparative investigation of microstructure, mechanical properties and strengthening mechanisms of Al-12Si/TiB2 fabricated by selective laser melting and hot pressing. Ceram. Int. 2018, 44, 17635-17642. [CrossRef] 
22. Maity, T.; Chawake, N.; Kim, J.; Eckert, J.; Prashanth, K. Anisotropy in local microstructure-Does it affect the tensile properties of the SLM samples? Manuf. Lett. 2018, 15, 33-37. [CrossRef]

23. Whenish, R.; Antony, M.; Balaji, T.; Selvam, A. Design and performance of additively manufactured lightweight bionic hand Design and Performance of Additively Manufactured Lightweight Bionic Hand. AIP Conf. Proc. 2021, $2317,020028$.

24. Wang, Z.; Xie, M.; Li, Y.; Zhang, W.; Yang, C.; Kollo, L.; Eckert, J.; Prashanth, K.G. Premature failure of an additively manufactured material. NPG Asia Mater. 2020, 12, 1-10. [CrossRef]

25. Babu, S.; Goodridge, R. Additive manufacturing. Mater. Sci. Technol. 2014, 31, 881-883. [CrossRef]

26. Attar, H.; Prashanth, K.G.; Zhang, L.-C.; Calin, M.; Okulov, I.V.; Scudino, S.; Yang, C.; Eckert, J. Effect of Powder Particle Shape on the Properties of In Situ Ti-TiB Composite Materials Produced by Selective Laser Melting. J. Mater. Sci. Technol. 2015, 31, 1001-1005. [CrossRef]

27. Attar, H.; Prashanth, K.; Chaubey, A.; Calin, M.; Zhang, L.; Scudino, S.; Eckert, J. Comparison of wear properties of commercially pure titanium prepared by selective laser melting and casting processes. Mater. Lett. 2015, 142, 38-41. [CrossRef]

28. Additive Manufacturing Market Analysis by Material Type, by Metal Type, by Polymer Type, by Ceramics Type, by Process, by End-Use, and Segment Forecasts to 2027. Research and Markets. 2020. Available online: https:/ / www.researchandmarkets.com/ reports/5206602/additive-manufacturing-market-analysis-by (accessed on 3 July 2021).

29. Singh, N.; Hameed, P.; Ummethala, R.; Manivasagam, G.; Prashanth, K.; Eckert, J. Selective laser manufacturing of Ti-based alloys and composites: Impact of process parameters, application trends, and future prospects. Mater. Today Adv. 2020, 8, 100097. [CrossRef]

30. Wang, Z.; Ummethala, R.; Singh, N.; Tang, S.; Suryanarayana, C.; Eckert, J.; Prashanth, K.G. Selective Laser Melting of Aluminum and Its Alloys. Materials 2020, 13, 4564. [CrossRef]

31. Wang, P.; Eckert, J.; Prashanth, K.-G.; Wu, M.-W.; Kaban, I.; Xi, L.-X.; Scudino, S. A review of particulate-reinforced aluminum matrix composites fabricated by selective laser melting. Trans. Nonferrous Met. Soc. China 2020, 30, 2001-2034. [CrossRef]

32. Salman, O.O.O.; Gammer, C.; Eckert, J.; Salih, M.Z.Z.; Abdulsalam, E.H.H.; Prashanth, K.G.G.; Scudino, S. Selective laser melting of 316L stainless steel: Influence of TiB2 addition on microstructure and mechanical properties. Mater. Today Commun. 2019, 21, 100615. [CrossRef]

33. Hameed, P.; Liu, C.-F.; Ummethala, R.; Singh, N.; Huang, H.-H.; Manivasagam, G.; Prashanth, K.G. Biomorphic porous Ti6Al4V gyroid scaffolds for bone implant applications fabricated by selective laser melting. Prog. Addit. Manuf. 2021, 6, 455-469. [CrossRef]

34. Velasco-Hogan, A.; Xu, J.; Meyers, M.A. Additive Manufacturing as a Method to Design and Optimize Bioinspired Structures. Adv. Mater. 2018, 30, 1800940. [CrossRef]

35. Selvam, A.; Mayilswamy, S.; Whenish, R. Strength Improvement of Additive Manufacturing Components by Reinforcing Carbon Fiber and by Employing Bioinspired Interlock Sutures. J. Vinyl Addit. Technol. 2020, 26, 511-523. [CrossRef]

36. Sharma, N.; Ostas, D.; Rotar, H.; Brantner, P.; Thieringer, F.M. Design and Additive Manufacturing of a Biomimetic Customized Cranial Implant Based on Voronoi Diagram. Front. Physiol. 2021, 12, 647923. [CrossRef]

37. Mahmoud, D.; Elbestawi, M.A. Lattice Structures and Functionally Graded Materials Applications in Additive Manufacturing of Orthopedic Implants: A Review. J. Manuf. Mater. Process. 2017, 1, 13. [CrossRef]

38. Kladovasilakis, N.; Tsongas, K.; Tzetzis, D. Finite Element Analysis of Orthopedic Hip Implant with Functionally Graded Bioinspired Lattice Structures. Biomimetics 2020, 5, 44. [CrossRef] [PubMed]

39. Robles-Linares, J.A.; Ramírez-Cedillo, E.; Siller, H.R.; Rodríguez, C.A.; Martínez-López, J.I. Parametric Modeling of Biomimetic Cortical Bone Microstructure for Additive Manufacturing. Materials 2019, 12, 913. [CrossRef] [PubMed]

40. Maguire, A.; Pottackal, N.; Saadi, M.A.S.R.; Rahman, M.M.; Ajayan, P.M. Additive manufacturing of polymer-based structures by extrusion technologies. Oxf. Open Mater. Sci. 2020, 1, itaa004. [CrossRef]

41. Wu, X.; Zhang, C.; Goldberg, P.; Cohen, D.; Pan, Y.; Arpin, T.; Bar-Yosef, O. Early Pottery at 20,000 Years Ago in Xianrendong Cave, China. Science 2012, 336, 1696-1700. [CrossRef] [PubMed]

42. Darsell, J.; Bose, S.; Hosick, H.L.; Bandyopadhyay, A. From CT Scan to Ceramic Bone Graft. J. Am. Ceram. Soc. 2003, 86, 1076-1080. [CrossRef]

43. Kamboj, N.; Rodríguez, M.A.; Rahmani, R.; Prashanth, K.G.; Hussainova, I. Bioceramic scaffolds by additive manufacturing for controlled delivery of the antibiotic vancomycin. Proc. Est. Acad. Sci. 2019, 68, 185-190. [CrossRef]

44. Holovenko, Y.; Kollo, L.; Saarna, M.; Rahmani, R.; Soloviova, T.; Antonov, M.; Prashanth, K.G.; Cygan, S.; Veinthal, R. Effect of lattice surface treatment on performance of hardmetal-Titanium interpenetrating phase composites. Int. J. Refract. Met. Hard Mater. 2019, 86, 105087. [CrossRef]

45. Rahmani, R.; Antonov, M.; Kollo, L.; Holovenko, Y.; Prashanth, K.G. Mechanical Behavior of Ti6Al4V Scaffolds Filled with CaSiO3 for Implant Applications. Appl. Sci. 2019, 9, 3844. [CrossRef]

46. Rahmani, R.; Brojan, M.; Antonov, M.; Prashanth, K.G. Perspectives of metal-diamond composites additive manufacturing using SLM-SPS and other techniques for increased wear-impact resistance. Int. J. Refract. Met. Hard Mater. 2020, 88, 105192. [CrossRef]

47. Aramian, A.; Sadeghian, Z.; Prashanth, K.G.; Berto, F. In situ fabrication of TiC-NiCr cermets by selective laser melting. Int. J. Refract. Met. Hard Mater. 2019, 87, 105171. [CrossRef]

48. Aramian, A.; Sadeghian, Z.; Razavi, S.M.J.; Prashanth, K.G.; Berto, F. Effect of selective laser melting process parameters on microstructural and mechanical properties of TiC-NiCr cermet. Ceram. Int. 2020, 46, 28749-28757. [CrossRef] 
49. Wang, Z.; Tang, S.; Scudino, S.; Ivanov, Y.; Qu, R.; Wang, D.; Yang, C.; Zhang, W.; Greer, A.; Eckert, J.; et al. Additive manufacturing of a martensitic Co-Cr-Mo alloy: Towards circumventing the strength-ductility trade-off. Addit. Manuf. 2020, 37, 101725. [CrossRef]

50. Miranda, P.; Saiz, E.; Gryn, K.; Tomsia, A.P. Sintering and robocasting of $\beta$-tricalcium phosphate scaffolds for orthopaedic applications. Acta Biomater. 2006, 2, 457-466. [CrossRef] [PubMed]

51. Myers, K.; Cortes, P.; Conner, B.; Wagner, T.; Hetzel, B.; Peters, K. Structure property relationship of metal matrix syntactic foams manufactured by a binder jet printing process. Addit. Manuf. 2014, 5, 54-59. [CrossRef]

52. Vaezi, M.; Yang, S. Freeform fabrication of nanobiomaterials using 3D printing. Rapid Prototyp. Biomater. 2014, 41-92. [CrossRef]

53. Harrer, W.; Schwentenwein, M.; Lube, T.; Danzer, R. Fractography of zirconia-specimens made using additive manufacturing (LCM) technology. J. Eur. Ceram. Soc. 2017, 37, 4331-4338. [CrossRef]

54. Bhaskar, S.; Lim, S. Engineering protein nanocages as carriers for biomedical applications. NPG Asia Mater. 2017,9 , e371. [CrossRef]

55. Holzwarth, J.M.; Ma, P.X. Biomimetic nanofibrous scaffolds for bone tissue engineering. Biomaterials 2011, 32, 9622-9629. [CrossRef] [PubMed]

56. Barabaschi, G.D.G.; Manoharan, V.; Li, Q.; Bertassoni, L.E. Engineering Pre-vascularized Scaffolds for Bone Regeneration. In Engineering Mineralized and Load Bearing Tissues; Springer: Berlin/Heidelberg, Germany, 2015; Volume 881, pp. 79-94. [CrossRef]

57. Launey, M.E.; Munch, E.; Alsem, D.H.; Saiz, E.; Tomsia, A.P.; Ritchie, R.O. A novel biomimetic approach to the design of high-performance ceramic-metal composites. J. R. Soc. Interface 2009, 7, 741-753. [CrossRef]

58. Moon, Y.-W.; Choi, I.-J.; Koh, Y.-H.; Kim, H.-E. Porous alumina ceramic scaffolds with biomimetic macro/micro-porous structure using three-dimensional (3-D) ceramic/camphene-based extrusion. Ceram. Int. 2015, 41, 12371-12377. [CrossRef]

59. Vijayavenkataraman, S.; Kuan, L.Y.; Lu, W.F. 3D-printed ceramic triply periodic minimal surface structures for design of functionally graded bone implants. Mater. Des. 2020, 191, 108602. [CrossRef]

60. Stanciuc, A.-M.; Sprecher, C.M.; Adrien, J.; Roiban, L.I.; Alini, M.; Gremillard, L.; Peroglio, M. Robocast zirconia-toughened alumina scaffolds: Processing, structural characterisation and interaction with human primary osteoblasts. J. Eur. Ceram. Soc. 2018, 38, 845-853. [CrossRef]

61. Bose, S.; Darsell, J.; Kintner, M.; Hosick, H.; Bandyopadhyay, A. Pore size and pore volume effects on alumina and TCP ceramic scaffolds. Mater. Sci. Eng. C 2003, 23, 479-486. [CrossRef]

62. Dawson, J.; Wahl, D.A.; Lanham, S.A.; Kanczler, J.; Czernuszka, J.T.; Oreffo, R. Development of specific collagen scaffolds to support the osteogenic and chondrogenic differentiation of human bone marrow stromal cells. Biomaterials 2008, 29, 3105-3116. [CrossRef]

63. Ge, X.; Zhao, J.; Esmeryan, K.D.; Lu, X.; Li, Z.; Wang, K.; Ren, F.; Wang, Q.; Wang, M.; Qian, B. Cicada-inspired fluoridated hydroxyapatite nanostructured surfaces synthesized by electrochemical additive manufacturing. Mater. Des. 2020, 193, 108790. [CrossRef]

64. Wu, S.; Zuber, F.; Maniura-Weber, K.; Brugger, J.; Ren, Q. Nanostructured surface topographies have an effect on bactericidal activity. J. Nanobiotechnology 2018, 16, 1-9. [CrossRef]

65. Kavasi, R.-M.; Coelho, C.; Platania, V.; Quadros, P.; Chatzinikolaidou, M. In Vitro Biocompatibility Assessment of NanoHydroxyapatite. Nanomaterials 2021, 11, 1152. [CrossRef]

66. Montalbano, G.; Molino, G.; Fiorilli, S.; Vitale-Brovarone, C. Synthesis and incorporation of rod-like nano-hydroxyapatite into type I collagen matrix: A hybrid formulation for 3D printing of bone scaffolds. J. Eur. Ceram. Soc. 2020, 40, 3689-3697. [CrossRef]

67. Luo, Y.; Zhai, D.; Huan, Z.; Zhu, H.; Xia, L.; Chang, J.; Wu, C. Three-Dimensional Printing of Hollow-Struts-Packed Bioceramic Scaffolds for Bone Regeneration. ACS Appl. Mater. Interfaces 2015, 7, 24377-24383. [CrossRef]

68. Stevanovic, S.; Chavanne, P.; Braissant, O.; Pieles, U.; Gruner, P.; Schumacher, R. Improvement of Mechanical Properties of 3d Printed Hydroxyapatite Scaffolds by Polymeric Infiltration. Bioceram. Dev. Appl. 2013, 3, 10-12. [CrossRef]

69. Li, X.; Yuan, Y.; Liu, L.; Leung, Y.-S.; Chen, Y.; Guo, Y.; Chai, Y.; Chen, Y. 3D printing of hydroxyapatite/tricalcium phosphate scaffold with hierarchical porous structure for bone regeneration. Bio-Design Manuf. 2019, 3, 15-29. [CrossRef]

70. Chen, G.; Sun, Y.; Lu, F.; Jiang, A.; Subedi, D.; Kong, P.; Wang, X.; Yu, T.; Chi, H.; Song, C.; et al. A three-dimensional (3D) printed biomimetic hierarchical scaffold with a covalent modular release system for osteogenesis. Mater. Sci. Eng. C 2019, 104, 109842. [CrossRef] [PubMed]

71. Chang, C.-H.; Lin, C.-Y.; Liu, F.-H.; Chen, M.H.-C.; Lin, C.-P.; Ho, H.-N.; Liao, Y.-S. 3D Printing Bioceramic Porous Scaffolds with Good Mechanical Property and Cell Affinity. PLoS ONE 2015, 10, e0143713. [CrossRef]

72. Maazouz, Y.; Montufar, E.B.; Guillem-Marti, J.; Fleps, I.; Öhman, C.; Persson, C.; Ginebra, M.P. Robocasting of biomimetic hydroxyapatite scaffolds using self-setting inks. J. Mater. Chem. B 2014, 2, 5378-5386. [CrossRef] [PubMed]

73. Chen, S.; Shi, Y.; Zhang, X.; Ma, J. Biomimetic synthesis of Mg-substituted hydroxyapatite nanocomposites and three-dimensional printing of composite scaffolds for bone regeneration. J. Biomed. Mater. Res. Part A 2019, 107, 2512-2521. [CrossRef]

74. Thammarakcharoen, F.; Suwanprateeb, J. Biomimetically Co-Deposition of Bovine Serum Albumin and Calcium Phosphate on 3D Printed Hydroxyapatite: Influence of Time, Temperature and Concentration. Key Eng. Mater. 2018, 766, 83-87. [CrossRef]

75. Thammarakcharoen, F.; Suwanprateeb, J. Effect of Process Parameters on Biomimetic Deposition of Calcium Phosphate on 3D Printed Hydroxyapatite. Key Eng. Mater. 2017, 751, 599-604. [CrossRef] 
76. Jalota, S.; Bhaduri, S.B.; Tas, A.C. In vitro testing of calcium phosphate (HA, TCP, and biphasic HA-TCP) whiskers. J. Biomed. Mater. Res. Part A 2006, 78, 481-490. [CrossRef] [PubMed]

77. Mygind, T.; Stiehler, M.; Baatrup, A.; Li, H.; Zou, X.; Flyvbjerg, A.; Kassem, M.; Bünger, C. Mesenchymal stem cell ingrowth and differentiation on coralline hydroxyapatite scaffolds. Biomaterials 2007, 28, 1036-1047. [CrossRef] [PubMed]

78. Yang, W.-F.; Long, L.; Wang, R.; Chen, D.; Duan, S.; Xu, F.-J. Surface-Modified Hydroxyapatite Nanoparticle-Reinforced Polylactides for Three-Dimensional Printed Bone Tissue Engineering Scaffolds. J. Biomed. Nanotechnol. 2018, 14, $294-303$. [CrossRef]

79. Tarafder, S.; Bose, S. Polycaprolactone-Coated 3D Printed Tricalcium Phosphate Scaffolds for Bone Tissue Engineering: In Vitro Alendronate Release Behavior and Local Delivery Effect on In Vivo Osteogenesis. ACS Appl. Mater. Interfaces 2014, 6, 9955-9965. [CrossRef]

80. Canillas, M.; Pena, P.; de Aza, A.H.; Rodríguez, M.A. Calcium phosphates for biomedical applications. Boletín Soc. Española Cerámica Vidr. 2017, 56, 91-112. [CrossRef]

81. Fielding, G.; Bose, S. SiO2 and $\mathrm{ZnO}$ dopants in three-dimensionally printed tricalcium phosphate bone tissue engineering scaffolds enhance osteogenesis and angiogenesis in vivo. Acta Biomater. 2013, 9, 9137-9148. [CrossRef]

82. Bose, S.; Tarafder, S.; Bandyopadhyay, A. Effect of Chemistry on Osteogenesis and Angiogenesis Towards Bone Tissue Engineering Using 3D Printed Scaffolds. Ann. Biomed. Eng. 2016, 45, 261-272. [CrossRef]

83. Bidgoli, M.R.; Alemzadeh, I.; Tamjid, E.; Khafaji, M.; Vossoughi, M. Fabrication of hierarchically porous silk fibroin-bioactive glass composite scaffold via indirect 3D printing: Effect of particle size on physico-mechanical properties and in vitro cellular behavior. Mater. Sci. Eng. C 2019, 103, 109688. [CrossRef]

84. Guo, X.; Zheng, Q.; Yang, S.; Shao, Z.; Yuan, Q.; Pan, Z.; Tang, S.; Liu, K.; Quan, D. Repair of full-thickness articular cartilage defects by cultured mesenchymal stem cells transfected with the transforming growth factor $\beta 1$ gene. Biomed. Mater. 2006, 1 , 206-215. [CrossRef]

85. Mastrogiacomo, M.; Muraglia, A.; Komlev, V.; Peyrin, F.; Rustichelli, F.; Crovace, A.; Cancedda, R. Tissue engineering of bone: Search for a better scaffold. Orthod. Craniofacial Res. 2005, 8, 277-284. [CrossRef]

86. Singh, S.; Ramakrishna, S.; Singh, R. Material issues in additive manufacturing: A review. J. Manuf. Process. 2017, 25, 185-200. [CrossRef]

87. Ha, N.S.; Lu, G. A review of recent research on bio-inspired structures and materials for energy absorption applications. Compos. Part B Eng. 2019, 181, 107496. [CrossRef]

88. Nguyen, N.A.; Barnes, S.H.; Bowland, C.C.; Meek, K.M.; Littrell, K.C.; Keum, J.K.; Naskar, A.K. A path for lignin valorization via additive manufacturing of high-performance sustainable composites with enhanced 3D printability. Sci. Adv. 2018, 4, eaat4967. [CrossRef] [PubMed]

89. Benmeridja, L.; De Moor, L.; De Maere, E.; Vanlauwe, F.; Ryx, M.; Tytgat, L.; Vercruysse, C.; Dubruel, P.; Van Vlierberghe, S.; Blondeel, P.; et al. High-throughput fabrication of vascularized adipose microtissues for 3D bioprinting. J. Tissue Eng. Regen. Med. 2020, 14, 840-854. [CrossRef] [PubMed]

90. Yu, G.Z.; Chou, D.-T.; Hong, D.; Roy, A.; Kumta, P.N. Biomimetic Rotated Lamellar Plywood Motifs by Additive Manufacturing of Metal Alloy Scaffolds for Bone Tissue Engineering. ACS Biomater. Sci. Eng. 2017, 3, 648-657. [CrossRef] [PubMed]

91. Whatley, B.R.; Kuo, J.; Shuai, C.; Damon, B.J.; Wen, X. Fabrication of a biomimetic elastic intervertebral disk scaffold using additive manufacturing. Biofabrication 2011, 3, 015004. [CrossRef]

92. Limmahakhun, S.; Oloyede, A.; Sitthiseripratip, K.; Xiao, Y.; Yan, C. 3D-printed cellular structures for bone biomimetic implants. Addit. Manuf. 2017, 15, 93-101. [CrossRef]

93. Silva, M.; Felismina, R.; Mateus, A.; Parreira, P.; Malça, C. Application of a Hybrid Additive Manufacturing Methodology to Produce a Metal/Polymer Customized Dental Implant. Procedia Manuf. 2017, 12, 150-155. [CrossRef]

94. Sabaté Rovira, D.; Nielsen, H.M.; Taboryski, R.; Bunea, A.-I. Additive manufacturing of polymeric scaffolds for biomimetic cell membrane engineering. Mater. Des. 2021, 201, 109486. [CrossRef]

95. Chan, W.W.; Yeo, D.C.L.; Tan, V.; Singh, S.; Choudhury, D.; Naing, M.W. Additive Biomanufacturing with Collagen Inks. Bioengineering 2020, 7, 66. [CrossRef] [PubMed]

96. Li, J.; Wu, C.; Chu, P.K.; Gelinsky, M. 3D printing of hydrogels: Rational design strategies and emerging biomedical applications. Mater. Sci. Eng. R Rep. 2020, 140, 100543. [CrossRef]

97. Zafeiris, K.; Brasinika, D.; Karatza, A.; Koumoulos, E.; Karoussis, I.; Kyriakidou, K.; Charitidis, C. Additive manufacturing of hydroxyapatite-chitosan-genipin composite scaffolds for bone tissue engineering applications. Mater. Sci. Eng. C 2020, 119, 111639. [CrossRef]

98. Del Bakhshayesh, A.R.; Asadi, N.; Alihemmati, A.; Nasrabadi, H.T.; Montaseri, A.; Davaran, S.; Saghati, S.; Akbarzadeh, A.; Abedelahi, A. An overview of advanced biocompatible and biomimetic materials for creation of replacement structures in the musculoskeletal systems: Focusing on cartilage tissue engineering. J. Biol. Eng. 2019, 9, 1-21. [CrossRef] [PubMed]

99. Ashammakhi, N.; Ahadian, S.; Xu, C.; Montazerian, H.; Ko, H.; Nasiri, R.; Barros, N.; Khademhosseini, A. Bioinks and bioprinting technologies to make heterogeneous and biomimetic tissue constructs. Mater. Today Bio 2019, 1, 100008. [CrossRef]

100. Cui, X.; Boland, T. Human microvasculature fabrication using thermal inkjet printing technology. Biomaterials 2009, 30, 6221-6227. [CrossRef] 
101. Hajiali, F.; Tajbakhsh, S.; Shojaei, A. Fabrication and Properties of Polycaprolactone Composites Containing Calcium PhosphateBased Ceramics and Bioactive Glasses in Bone Tissue Engineering: A Review. Polym. Rev. 2017, 58, 164-207. [CrossRef]

102. Wang, L.; He, S.; Wu, X.; Liang, S.; Mu, Z.; Wei, J.; Deng, F.; Deng, Y.; Wei, S. Polyetheretherketone/nano-fluorohydroxyapatite composite with antimicrobial activity and osseointegration properties. Biomaterials 2014, 35, 6758-6775. [CrossRef]

103. Yoo, D.-J. Recent trends and challenges in computer-aided design of additive manufacturing-based biomimetic scaffolds and bioartificial organs. Int. J. Precis. Eng. Manuf. 2014, 15, 2205-2217. [CrossRef]

104. Wu, Y.; Lin, Z.Y.; Wenger, A.C.; Tam, K.C.; Tang, X. 3D bioprinting of liver-mimetic construct with alginate/cellulose nanocrystal hybrid bioink. Bioprinting 2018, 9, 1-6. [CrossRef]

105. Srinivasan, R.; Pridhar, T.; Sree Charan, N.; Ramprasath, L.; Charan, N.S.; Ruban, W. Prediction of tensile strength in FDM printed ABS parts using response surface methodology (RSM). Mater. Today Proc. 2020, 27, 1827-1832. [CrossRef]

106. Singh, M.; Jonnalagadda, S. Advances in bioprinting using additive manufacturing. Eur. J. Pharm. Sci. 2019, $143,105167$. [CrossRef]

107. Christensen, K.; Xu, C.; Chai, W.; Zhang, Z.; Fu, J.; Huang, Y. Freeform inkjet printing of cellular structures with bifurcations. Biotechnol. Bioeng. 2014, 112, 1047-1055. [CrossRef]

108. Ding, C.; Qiao, Z.; Jiang, W.; Li, H.; Wei, J.; Zhou, G.; Dai, K. Regeneration of a goat femoral head using a tissue-specific, biphasic scaffold fabricated with CAD/CAM technology. Biomaterials 2013, 34, 6706-6716. [CrossRef]

109. Zhang, W.; Lian, Q.; Li, D.; Wang, K.; Hao, D.; Bian, W.; Jin, Z. The effect of interface microstructure on interfacial shear strength for osteochondral scaffolds based on biomimetic design and 3D printing. Mater. Sci. Eng. C 2015, 46, 10-15. [CrossRef] [PubMed]

110. Liu, A.; Xue, G.-H.; Sun, M.; Shao, H.-F.; Ma, C.-Y.; Gao, Q.; Gou, Z.-R.; Yan, S.-G.; Liu, Y.-M.; He, Y. 3D Printing Surgical Implants at the clinic: A Experimental Study on Anterior Cruciate Ligament Reconstruction. Sci. Rep. 2016, 6, 21704. [CrossRef] [PubMed]

111. Mukhopadhyay, P.; Sarkar, K.; Bhattacharya, S.; Bhattacharyya, A.; Mishra, R.; Kundu, P. pH sensitive N-succinyl chitosan grafted polyacrylamide hydrogel for oral insulin delivery. Carbohydr. Polym. 2014, 112, 627-637. [CrossRef] [PubMed]

112. Stroganov, V. 4D Biofabrication Using Self-Folding Polymers. Ph.D. Thesis, University of Bayreuth, Bayreuth, Germany, 2018.

113. Wan, Z.; Zhang, P.; Liu, Y.; Lv, L.; Zhou, Y. Four-dimensional bioprinting: Current developments and applications in bone tissue engineering. Acta Biomater. 2019, 101, 26-42. [CrossRef]

114. Abraham, C.M. A Brief Historical Perspective on Dental Implants, Their Surface Coatings and Treatments. Open Dent. J. 2014, 8, 50-55. [CrossRef]

115. Saini, M. Implant biomaterials: A comprehensive review. World J. Clin. Cases 2015, 3, 52-57. [CrossRef]

116. Katti, K.; Verma, D. Materials for joint replacement. In Joint Replacement Technology; Woodhead Publishing: Cambridge, UK, 2008; pp. 81-104. [CrossRef]

117. Chen, Q.; Thouas, G.A. Metallic implant biomaterials. Mater. Sci. Eng. R Rep. 2015, 87, 1-57. [CrossRef]

118. Ummethala, R.; Karamched, P.S.; Rathinavelu, S.; Singh, N.; Aggarwal, A.; Sun, K.; Ivanov, E.; Kollo, L.; Okulov, I.; Eckert, J.; et al. Selective laser melting of high-strength, low-modulus Ti-35Nb-7Zr-5Ta alloy. Materialia 2020, 14, 100941. [CrossRef]

119. Schwab, H.; Prashanth, K.G.; Löber, L.; Kühn, U.; Eckert, J. Selective Laser Melting of Ti-45Nb Alloy. Metals 2015, 5, 686-694. [CrossRef]

120. Zhuravleva, K.; Bönisch, M.; Prashanth, K.G.; Hempel, U.; Helth, A.; Gemming, T.; Calin, M.; Scudino, S.; Schultz, L.; Eckert, J.; et al. Production of Porous $\beta$-Type Ti-40Nb Alloy for Biomedical Applications: Comparison of Selective Laser Melting and Hot Pressing. Materials 2013, 6, 5700-5712. [CrossRef] [PubMed]

121. Ridzwan, M.I.Z.; Shuib, S.; Hassan, A.Y.; Shokri, A.A.; Mohammad Ibrahim, M.N. Problem of Stress Shielding and Improvement to the Hip Implant Designs: A Review. J. Med Sci. 2007, 7, 460-467. [CrossRef]

122. Gong, Q.; Hu, X. Photonic crystals: Principles and applications. MRS Bull. 2014, 39, 824-825. [CrossRef]

123. Nicholson, J.W. Titanium Alloys for Dental Implants: A Review. Prosthesis 2020, 2, 100-116. [CrossRef]

124. Bone Healing_Physiopedia. Available online: https:/ / www.physio-pedia.com/Bone_Healing (accessed on 3 June 2021).

125. Arabnejad, S.; Johnston, B.; Tanzer, M.; Pasini, D. Fully porous 3D printed titanium femoral stem to reduce stress-shielding following total hip arthroplasty. J. Orthop. Res. 2016, 35, 1774-1783. [CrossRef]

126. Prasad, K.; Bazaka, O.; Chua, M.; Rochford, M.; Fedrick, L.; Spoor, J.; Symes, R.; Tieppo, M.; Collins, C.; Cao, A.; et al. Metallic Biomaterials: Current Challenges and Opportunities. Materials 2017, 10, 884. [CrossRef]

127. Rotta, G.; Seramak, T.; Zasinska, K. Estimation of Young's Modulus of the Porous Titanium Alloy with the Use of Fem Package. Adv. Mater. Sci. 2015, 15, 29-37. [CrossRef]

128. Mehboob, H.; Tarlochan, F.; Mehboob, A.; Chang, S.-H.; Ramesh, S.; Harun, W.S.W.; Kadirgama, K. A novel design, analysis and 3D printing of Ti-6Al-4V alloy bio-inspired porous femoral stem. J. Mater. Sci. Mater. Med. 2020, 31, 1-14. [CrossRef] [PubMed]

129. Kim, J.-H.; Kim, M.-Y.; Knowles, J.C.; Choi, S.; Kang, H.; Park, S.-H.; Park, S.-M.; Kim, H.-W.; Park, J.-T.; Lee, J.-H.; et al. Mechanophysical and biological properties of a 3D-printed titanium alloy for dental applications. Dent. Mater. 2020, 36, 945-958. [CrossRef]

130. El-Hajje, A.; Kolos, E.C.; Wang, J.K.; Maleksaeedi, S.; He, Z.; Wiria, F.E.; Choong, C.; Ruys, A.J. Physical and mechanical characterisation of 3D-printed porous titanium for biomedical applications. J. Mater. Sci. Mater. Med. 2014, 25, 2471-2480. [CrossRef] 
131. Miura, H.; Okawachi, K.; Kang, H.G.; Tsumori, F.; Kurata, K.; Arimoto, N. Laser Forming of Ti-6Al-7Nb Alloy Porous Parts for Medical Devices; Trans Tech Publications, Ltd.: Bäch, Switzerland, 2010; Available online: https://www.pm-review.com/articles/ laser-forming-of-ti-6al-7nb-alloy-porous-parts-for-medical-devices/ (accessed on 20 August 2021).

132. Szymczyk, P.; Ziółkowski, G.; Junka, A.; Chlebus, E. Application of Ti6Al7Nb Alloy for the Manufacture of Biomechanical Functional Structures (BFS) for Custom-Made Bone Implants. Materials 2018, 11, 971. [CrossRef] [PubMed]

133. Verlee, B.; Dormal, T.; Lecomte-Beckers, J. Density and porosity control of sintered 316L stainless steel parts produced by additive manufacturing. Powder Met. 2012, 55, 260-267. [CrossRef]

134. Čapek, J.; Machová, M.; Fousová, M.; Kubásek, J.; Vojtěch, D.; Fojt, J.; Jablonská, E.; Lipov, J.; Ruml, T. Highly porous, low elastic modulus 316L stainless steel scaffold prepared by selective laser melting. Mater. Sci. Eng. C 2016, 69, 631-639. [CrossRef]

135. Bobbert, F.; Lietaert, K.; Eftekhari, A.A.; Pouran, B.; Ahmadi, S.; Weinans, H.; Zadpoor, A.A. Additively manufactured metallic porous biomaterials based on minimal surfaces: A unique combination of topological, mechanical, and mass transport properties. Acta Biomater. 2017, 53, 572-584. [CrossRef]

136. Bai, L.; Gong, C.; Chen, X.; Sun, Y.; Zhang, J.; Cai, L.; Zhu, S.; Xie, S.Q. Additive Manufacturing of Customized Metallic Orthopedic Implants: Materials, Structures, and Surface Modifications. Metals 2019, 9, 1004. [CrossRef]

137. Van Bael, S.; Chai, Y.C.; Truscello, S.; Moesen, M.; Kerckhofs, G.; Van Oosterwyck, H.; Kruth, J.-P.; Schrooten, J. The effect of pore geometry on the in vitro biological behavior of human periosteum-derived cells seeded on selective laser-melted Ti6Al4V bone scaffolds. Acta Biomater. 2012, 8, 2824-2834. [CrossRef]

138. Hollander, D.A.; Wirtz, T.; von Walter, M.; Linker, R.; Schultheis, A.; Paar, O. Development of Individual Three-Dimensional Bone Substitutes Using "Selective Laser Melting". Eur. J. Trauma Emerg. Surg. 2003, 29, 228-234. [CrossRef]

139. Anatomography. Wikipedia, via Wikimedia Commons. 2021. Available online: https://en.wikipedia.org/wiki/Anatomography (accessed on 6 July 2021).

140. Siemer, P. Wikipedia, via Wikimedia Commons. Available online: https://creativecommons.org/licenses/by/2.0\%3E (accessed on 6 July 2021).

141. Chung, K.J.; Hong, D.Y.; Kim, Y.T.; Yang, I.; Park, Y.W.; Kim, H.N. Preshaping Plates for Minimally Invasive Fixation of Calcaneal Fractures Using a Real-Size 3D-Printed Model as a Preoperative and Intraoperative Tool. Foot Ankle Int. 2014, 35, 1231-1236. [CrossRef] [PubMed]

142. Starosolski, Z.A.; Kan, J.H.; Rosenfeld, S.D.; Krishnamurthy, R.; Annapragada, A. Application of 3-D printing (rapid prototyping) for creating physical models of pediatric orthopedic disorders. Pediatr. Radiol. 2013, 44, 216-221. [CrossRef]

143. Victor, J.; Dujardin, J.; Vandenneucker, H.; Arnout, N.; Bellemans, J. Patient-specific Guides Do Not Improve Accuracy in Total Knee Arthroplasty: A Prospective Randomized Controlled Trial. Clin. Orthop. Relat. Res. 2014, 472, 263-271. [CrossRef] [PubMed]

144. Guarino, J.; Tennyson, S.; McCain, G.; Bond, L.; Shea, K.; King, H. Rapid Prototyping Technology for Surgeries of the Pediatric Spine and Pelvis. J. Pediatr. Orthop. 2007, 27, 955-960. [CrossRef] [PubMed]

145. Victor, J.; Premanathan, A. Virtual 3D planning and patient specific surgical guides for osteotomies around the knee: A feasibility and proof-of-concept study. Bone Jt. J. 2013, 95, 153-158. [CrossRef]

146. Additive Manufacturing Market Report | Global Analysis \& Forecast. Reports and Data. Available online: https://www. reportsanddata.com/report-detail/additive-manufacturing-market (accessed on 17 November 2021).

147. Wang, P.; Li, H.; Prashanth, K.; Eckert, J.; Scudino, S. Selective laser melting of Al-Zn-Mg-Cu: Heat treatment, microstructure and mechanical properties. J. Alloy. Compd. 2017, 707, 287-290. [CrossRef]

148. Wang, P.; Gammer, C.; Brenne, F.; Prashanth, K.G.; Mendes, R.G.; Rümmeli, M.H.; Gemming, T.; Eckert, J.; Scudino, S. Microstructure and mechanical properties of a heat-treatable Al-3.5Cu-1.5Mg-1Si alloy produced by selective laser melting. Mater. Sci. Eng. A 2018, 711, 562-570. [CrossRef]

149. Jia, Y.D.; Ma, P.; Prashanth, K.G.; Wang, G.; Yi, J.; Scudino, S.; Cao, F.Y.; Sun, J.F.; Eckert, J. Microstructure and thermal expansion behavior of Al-50Si synthesized by selective laser melting. J. Alloys Compd. 2017, 699, 548-553. [CrossRef]

150. Mfusi, B.J.; Mathe, N.R.; Tshabalala, L.C.; Popoola, P.A. The Effect of Stress Relief on the Mechanical and Fatigue Properties of Additively Manufactured AlSi10Mg Parts. Metals 2019, 9, 1216. [CrossRef]

151. Roehling, J.D.; Smith, W.L.; Roehling, T.T.; Vrancken, B.; Guss, G.M.; McKeown, J.T.; Hill, M.R.; Matthews, M.J. Reducing residual stress by selective large-area diode surface heating during laser powder bed fusion additive manufacturing. Addit. Manuf. 2019, 28, 228-235. [CrossRef]

152. Li, C.; Liu, Z.; Fang, X.; Guo, Y. Residual Stress in Metal Additive Manufacturing. Procedia CIRP 2018, 71, 348-353. [CrossRef]

153. Tong, Z.; Ren, X.; Jiao, J.; Zhou, W.; Ren, Y.; Ye, Y.; Larson, E.A.; Gu, J. Laser additive manufacturing of FeCrCoMnNi high-entropy alloy: Effect of heat treatment on microstructure, residual stress and mechanical property. J. Alloy. Compd. 2019, 785, 1144-1159. [CrossRef]

154. Chen, X.; Li, J.; Cheng, X.; Wang, H.; Huang, Z. Effect of heat treatment on microstructure, mechanical and corrosion properties of austenitic stainless steel 316L using arc additive manufacturing. Mater. Sci. Eng. A 2018, 715, 307-314. [CrossRef]

155. Qi, Y.; Zhang, H.; Zhu, J.; Nie, X.; Hu, Z.; Zhu, H.; Zeng, X. Mechanical behavior and microstructure evolution of Al-Cu-Mg alloy produced by laser powder bed fusion: Effect of heat treatment. Mater. Charact. 2020, 165, 110364. [CrossRef]

156. Kumbhar, N.N.; Mulay, A.V. Post Processing Methods used to Improve Surface Finish of Products which are Manufactured by Additive Manufacturing Technologies: A Review. J. Inst. Eng. (India) Ser. C 2016, 99, 481-487. [CrossRef] 
157. Tan, K.; Yeo, S.H. Surface modification of additive manufactured components by ultrasonic cavitation abrasive finishing. Wear 2017, 378-379, 90-95. [CrossRef]

158. Witkin, D.B.; Patel, D.N.; Helvajian, H.; Steffeney, L.; Diaz, A. Surface Treatment of Powder-Bed Fusion Additive Manufactured Metals for Improved Fatigue Life. J. Mater. Eng. Perform. 2018, 28, 681-692. [CrossRef]

159. Imanishi, J.; Choong, P.F. Three-dimensional printed calcaneal prosthesis following total calcanectomy. Int. J. Surg. Case Rep. 2015, 10, 83-87. [CrossRef]

160. Ni, J.; Ling, H.; Zhang, S.; Wang, Z.; Peng, Z.; Benyshek, C.; Zan, R.; Miri, A.K.; Li, Z.; Zhang, X.; et al. Three-dimensional printing of metals for biomedical applications. Mater. Today Bio 2019, 3, 100024. [CrossRef]

161. Jardini, A.L.; Larosa, M.A.; Macedo, M.F.; Bernardes, L.F.; Lambert, C.S.; Zavaglia, C.A.C.; Filho, R.M.; Calderoni, D.R.; Ghizoni, E.; Kharmandayan, P. Improvement in Cranioplasty: Advanced Prosthesis Biomanufacturing. Procedia CIRP 2016, 49, 203-208. [CrossRef]

162. Chen, X.; Possel, J.K.; Wacongne, C.; van Ham, A.F.; Klink, C.; Roelfsema, P. 3D printing and modelling of customized implants and surgical guides for non-human primates. J. Neurosci. Methods 2017, 286, 38-55. [CrossRef] [PubMed]

163. Phan, K.; Sgro, A.; Maharaj, M.M.; D’Urso, P.; Mobbs, R.J. Application of a 3D custom printed patient specific spinal implant for C1/2 arthrodesis. J. Spine Surg. 2016, 2, 314-318. [CrossRef]

164. Dzian, A.; Zivcak, J.; Penciak, R.; Hudak, R. Implantation of a 3D-printed titanium sternum in a patient with a sternal tumor. World J. Surg. Oncol. 2018, 16, 7. [CrossRef]

165. Captiva Spine's TirboLOX-L Titanium Lumbar Cages Receives FDA Clearance. Available online: https://spinalnewsinternational. com/captiva-spine-tirbolox/ (accessed on 17 November 2021).

166. Wong, K.C.; Kumta, S.M.; Geel, N.V.; Demol, J. One-step reconstruction with a 3D-printed, biomechanically evaluated custom implant after complex pelvic tumor resection. Comput. Aided Surg. 2015, 20, 14-23. [CrossRef] [PubMed]

167. Shuang, F.; Hu, W.; Shao, Y.; Li, H.; Zou, H. Treatment of Intercondylar Humeral Fractures With 3D-Printed Osteosynthesis Plates. Medicine 2016, 95, e2461. [CrossRef]

168. Cranioplasty I Johns Hopkins Medicine. Available online: https://www.hopkinsmedicine.org/health/treatment-tests-andtherapies / cranioplasty (accessed on 15 June 2021).

169. Wind, J.; Cooke, R.S.; Gray, J.; Fannin, T.; Fegan, T. Medical rapid prototyping and 3D CT in the manufacture of custom made cranial titanium plates. J. Med. Eng. Technol. 1999, 23, 26-28. [CrossRef] [PubMed]

170. Mazzoli, A. Selective laser sintering in biomedical engineering. Med. Biol. Eng. Comput. 2012, 51, 245-256. [CrossRef] [PubMed]

171. Mazzoli, A.; Germani, M.; Raffaeli, R. Direct fabrication through electron beam melting technology of custom cranial implants designed in a PHANToM-based haptic environment. Mater. Des. 2009, 30, 3186-3192. [CrossRef]

172. Ran, Q.; Yang, W.; Hu, Y.; Shen, X.; Yu, Y.; Xiang, Y.; Cai, K. Osteogenesis of 3D printed porous Ti6Al4V implants with different pore sizes. J. Mech. Behav. Biomed. Mater. 2018, 84, 1-11. [CrossRef]

173. Marzola, A.; Buonamici, F.; Furferi, R.; Governi, L.; Genitori, L.; Mussa, F. Additive Manufacturing and Reverse Engineering in Cranioplasty: A Personalized Approach to Minimize Skin Flap Complications. Appl. Sci. 2021, 11, 4926. [CrossRef]

174. Cascino, T.; Shea, M.J. Percutaneous Coronary Interventions (PCI)—Cardiovascular Disorders—MSD Manual Professional Edition. Available online: https://www.msdmanuals.com/en-in/professional/cardiovascular-disorders/cardiovascular-testsand-procedures/percutaneous-coronary-interventions-pci (accessed on 15 June 2021).

175. Guerra, A.J.; Ciurana, J. Stent's Manufacturing Field: Past, Present, and Future Prospects. Angiography 2019. [CrossRef]

176. Demir, A.G.; Previtali, B. Additive manufacturing of cardiovascular CoCr stents by selective laser melting. Mater. Des. 2017, 119, 338-350. [CrossRef]

177. World's First 3D Printed Nitinol Stent-CSIRO. Available online: https://www.csiro.au/en/research/production/materials/3Dprinted-Nitinol-stent (accessed on 15 June 2021).

178. Orla, A.; Mcgee, M.; Geraghty, S.; Hughes, C.; Jamshidi, P.; Kenny, D.P.; Attallah, M.M.; Lally, C. An Investigation into PatientSpecific 3D Printed Titanium Stents and the use of Etching to Overcome Selective Laser Melting Design Constraints. bioRxiv 2021. [CrossRef]

179. Tilton, M.; Lewis, G.; Bok Wee, H.; Armstrong, A.; Hast, M.W.; Manogharan, G. Additive manufacturing of fracture fixation implants: Design, material characterization, biomechanical modeling and experimentation. Addit. Manuf. 2020, $33,101137$. [CrossRef]

180. Jason, A.; Lowe, M. AAOS. Available online: https://orthoinfo.aaos.org/en/treatment/internal-fixation-for-fractures/ (accessed on 16 June 2021).

181. Smith, K.E.; Dupont, K.M.; Safranski, D.L.; Blair, J.W.; Buratti, D.R.; Zeetser, V.; Callahan, R.; Lin, J.S.; Gall, K. Use of 3D Printed Bone Plate in Novel Technique to Surgically Correct Hallux Valgus Deformities. Tech. Orthop. 2016, 31, 181-189. [CrossRef] [PubMed]

182. Watson, J.N.; McQueen, P.; Kim, W.; Hutchinson, M.R. Bioabsorbable interference screw failure in anterior cruciate ligament reconstruction: A case series and review of the literature. Knee 2015, 22, 256-261. [CrossRef]

183. Harvey, A.; Thomas, N.P.; Amis, A.A. Fixation of the graft in reconstruction of the anterior cruciate ligament. J. Bone Jt. Surg. Ser. $B$ 2005, 87, 593-603. [CrossRef] 
184. Huang, Y.-M.; Huang, C.-C.; Tsai, P.-I.; Yang, K.-Y.; Huang, S.-I.; Shen, H.-H.; Lai, H.-J.; Huang, S.-W.; Chen, S.-Y.; Lin, F.-H.; et al. Three-Dimensional Printed Porous Titanium Screw with Bioactive Surface Modification for Bone-Tendon Healing: A Rabbit Animal Model. Int. J. Mol. Sci. 2020, 21, 3628. [CrossRef] [PubMed]

185. Zhang, Y.; Zhang, L.; Sun, R.; Jia, Y.; Chen, X.; Liu, Y.; Oyang, H.; Feng, L. A new 3D printed titanium metal trabecular bone reconstruction system for early osteonecrosis of the femoral head. Medicine 2018, 97, e11088. [CrossRef] [PubMed]

186. Cronskär, M. The Use of Additive Manufacturing in the Custom Design of Orthopedic Implants. Ph.D. Thesis, Mid Sweden University, Östersund, Sweden, 2011. Available online: http://miun.diva-portal.org/smash/record.jsf?pid=diva2:436633 (accessed on 17 June 2021).

187. Vundelinckx, B.J.; Bruckers, L.; De Mulder, K.; De Schepper, J.; Van Esbroeck, G. Functional and Radiographic Short-Term Outcome Evaluation of the Visionaire System, a Patient-Matched Instrumentation System for Total Knee Arthroplasty. J. Arthroplast. 2013, 28, 964-970. [CrossRef] [PubMed]

188. Stronach, B.M.; Pelt, C.E.; Erickson, J.; Peters, C.L. Patient-specific Total Knee Arthroplasty Required Frequent Surgeon-directed Changes knee. Clin. Orthop. Relat. Res. 2013, 471, 169-174. [CrossRef] [PubMed]

189. Maniar, R.N.; Singhi, T. Patient specific implants: Scope for the future. Curr. Rev. Musculoskelet. Med. 2014, 7, 125-130. [CrossRef]

190. Murr, L.E.; Gaytan, S.M.; Martinez, E.; Medina, F.; Wicker, R.B. Next Generation Orthopaedic Implants by Additive Manufacturing Using Electron Beam Melting. Int. J. Biomater. 2012, 2012, 1-14. [CrossRef]

191. Narra, S.P.; Mittwede, P.N.; DeVincent Wolf, S.; Urish, K.L. Additive Manufacturing in Total Joint Arthroplasty. Orthop. Clin. N. Am. 2019, 50, 13-20. [CrossRef] [PubMed]

192. Rib and Sternum Repair I UTMB Health I UTMB Home. Available online: https://www.utmbhealth.com/services/ cardiovascular-thoracic-surgery/procedures-conditions/chest-wall-repair/Rib-Sternum-Repair (accessed on 16 June 2021).

193. Rupprecht, L.; Schmid, C. Deep Sternal Wound Complications: An Overview of Old and new Therapeutic Options. Open J. Cardiovasc. Surg. 2013, 6, OJCS-S11199. [CrossRef]

194. Aragón, J.; Méndez, I.P. Dynamic 3D printed titanium copy prosthesis: A novel design for large chest wall resection and reconstruction. J. Thorac. Dis. 2016, 8, E385-E389. [CrossRef]

195. The Additive Manufacturing Trend in Spine Today. Available online: https://orthostreams.com/2018/05/the-additivemanufacturing-trend-in-spine-today/ (accessed on 17 June 2021).

196. Additively Manufactured Spinal Implants Mimic the Mechanical Properties of Bone. Available online: https:/ /www.eurekamagazine. co.uk/design-engineering-features/technology/3d-printed-spinal-implants-1/214814/ (accessed on 17 June 2021).

197. Sheha, E.D.; Gandhi, S.D.; Colman, M.W. 3D printing in spine surgery. Ann. Transl. Med. 2019, 7, S164. [CrossRef]

198. Burnard, J.L.; Parr, W.C.H.; Choy, W.J.; Walsh, W.R.; Mobbs, R.J. 3D-printed spine surgery implants: A systematic review of the efficacy and clinical safety profile of patient-specific and off-the-shelf devices. Eur. Spine J. 2019, 29, 1248-1260. [CrossRef]

199. Xu, N.; Wei, F.; Liu, X.; Jiang, L.; Cai, H.; Li, Z.; Yu, M.; Wu, F.; Liu, Z. Reconstruction of the Upper Cervical Spine Using a Personalized 3D-Printed Vertebral Body in an Adolescent With Ewing Sarcoma. Spine 2016, 41, E50-E54. [CrossRef]

200. Mobbs, R.J.; Parr, W.C.; Choy, W.J.; McEvoy, A.; Walsh, W.R.; Phan, K. Anterior Lumbar Interbody Fusion Using a Personalized Approach: Is Custom the Future of Implants for Anterior Lumbar Interbody Fusion Surgery? World Neurosurg. 2019, 124, 452-458.e1. [CrossRef] [PubMed]

201. Wei, R.; Guo, W.; Yang, R.; Tang, X.; Yang, Y.; Ji, T.; Liang, H. Reconstruction of the pelvic ring after total en bloc sacrectomy using a 3D-printed sacral endoprosthesis with re-establishment of spinopelvic stability: A retrospective comparative study. Bone Jt. J. 2019, 101B, 880-888. [CrossRef] [PubMed]

202. Breeland, G.; Patel, B.C. Anatomy, Head and Neck, Mandible; StatPearls Publishing: Treasure Island, FL, USA, 2019. Available online: http: / / www.ncbi.nlm.nih.gov / pubmed/30335325 (accessed on 17 June 2021).

203. Kumar, B.P.; Venkatesh, V.; Kumar, K.A.J.; Yadav, B.Y.; Mohan, S.R. Mandibular Reconstruction: Overview. J. Maxillofac. Oral Surg. 2015, 15, 425-441. [CrossRef]

204. Xia, Y.; Feng, Z.C.; Li, C.; Wu, H.; Tang, C.; Wang, L.; Li, H. Application of additive manufacturing in customized titanium mandibular implants for patients with oral tumors. Oncol. Lett. 2020, 20, 1. [CrossRef] [PubMed]

205. Park, J.-H.; Odkhuu, M.; Cho, S.; Li, J.; Park, B.-Y.; Kim, J.-W. 3D-printed titanium implant with pre-mounted dental implants for mandible reconstruction: A case report. Maxillofac. Plast. Reconstr. Surg. 2020, 42, 1-4. [CrossRef]

206. Gaviria, L.; Salcido, J.P.; Guda, T.; Ong, J.L. Current trends in dental implants. J. Korean Assoc. Oral Maxillofac. Surg. 2014, 40, 50-60. [CrossRef]

207. Pillai, S.; Upadhyay, A.; Khayambashi, P.; Farooq, I.; Sabri, H.; Tarar, M.; Lee, K.T.; Harb, I.; Zhou, S.; Wang, Y.; et al. Dental 3D-Printing: Transferring Art from the Laboratories to the Clinics. Polymers 2021, 13, 157. [CrossRef] [PubMed]

208. Barazanchi, A.; Li, K.C.; Al-Amleh, B.; Lyons, K.; Waddell, J. Additive Technology: Update on Current Materials and Applications in Dentistry. J. Prosthodont. 2016, 26, 156-163. [CrossRef]

209. Padrós, R.; Punset, M.; Molmeneu, M.; Velasco, A.B.; Herrero-Climent, M.; Rupérez, E.; Gil, F.J. Mechanical Properties of CoCr Dental-Prosthesis Restorations Made by Three Manufacturing Processes. Influence of the Microstructure and Topography. Metals 2020, 10, 788. [CrossRef]

210. Clinical Trial Finds 3D Printed Dentures are Preferred to Conventional Cast Metal Dentures-3D Printing Industry. Available online: https:/ /3dprintingindustry.com/news/clinical-trial-finds-3d-printed-dentures-preferred-conventional-cast-metaldentures-118320 / (accessed on 17 June 2021). 
211. Tunchel, S.; Blay, A.; Kolerman, R.; Mijiritsky, E.; Shibli, J.A. 3D Printing/Additive Manufacturing Single Titanium Dental Implants: A Prospective Multicenter Study with 3 Years of Follow-Up. Int. J. Dent. 2016, 2016, 1-9. [CrossRef]

212. Hesse, H.; Özcan, M. A review on current additive manufacturing technologies and materials used for fabrication of metal-ceramic fixed dental prosthesis. J. Adhes. Sci. Technol. 2021, 1-18. [CrossRef]

213. Ghassemi, T.; Shahroodi, A.; Ebrahimzadeh, M.H.; Mousavian, A.; Movaffagh, J.; Moradi, A. Current Concepts in Scaffolding for Bone Tissue Engineering. Arch. Bone Jt. Surg. 2018, 6, 90-99. [CrossRef]

214. Hutmacher, D.W. Scaffolds in tissue engineering bone and cartilage. Biomaterials 2000, 21, 2529-2543. [CrossRef]

215. Moniruzzaman, M.; O’Neal, C.; Bhuiyan, A.; Egan, P.F. Design and Mechanical Testing of 3D Printed Hierarchical Lattices Using Biocompatible Stereolithography. Designs 2020, 4, 22. [CrossRef]

216. De Wild, M.; Ghayor, C.; Zimmermann, S.; Rüegg, J.; Nicholls, F.; Schuler, F.; Chen, T.-H.; Weber, F.E. Osteoconductive Lattice Microarchitecture for Optimized Bone Regeneration. 3D Print. Addit. Manuf. 2019, 6, 40-49. [CrossRef]

217. Crovace, A.M.; Lacitignola, L.; Forleo, D.M.; Staffieri, F.; Francioso, E.; Di Meo, A.; Becerra, J.; Crovace, A.; Santos-Ruiz, L. 3D Biomimetic Porous Titanium ( $\mathrm{Ti}_{6} \mathrm{Al}_{4} \mathrm{~V}$ ELI) Scaffolds for Large Bone Critical Defect Reconstruction: An Experimental Study in Sheep. Animals 2020, 10, 1389. [CrossRef] [PubMed]

218. Moiduddin, K.; Darwish, S.; Al-Ahmari, A.; ElWatidy, S.; Mohammad, A.; Ameen, W. Structural and mechanical characterization of custom design cranial implant created using additive manufacturing. Electron. J. Biotechnol. 2017, 29, 22-31. [CrossRef]

219. Jardini, A.L.; Larosa, M.A.; Filho, R.M.; Zavaglia, C.A.D.C.; Bernardes, L.F.; Lambert, C.S.; Calderoni, D.R.; Kharmandayan, P. Cranial reconstruction: 3D biomodel and custom-built implant created using additive manufacturing. J. Cranio-Maxillofac. Surg. 2014, 42, 1877-1884. [CrossRef] [PubMed]

220. Jardini, A.L.; Larosa, M.A.; de Carvalho Zavaglia, C.A.; Bernardes, L.F.; Lambert, C.S.; Kharmandayan, P.; Calderoni, D.; Maciel Filho, R. Customised titanium implant fabricated in additive manufacturing for craniomaxillofacial surgery: This paper discusses the design and fabrication of a metallic implant for the reconstruction of a large cranial defect. Virtual Phys. Prototyp. 2014, 9, 115-125. [CrossRef]

221. Volpe, Y.; Furferi, R.; Governi, L.; Uccheddu, F.; Carfagni, M.; Mussa, F.; Scagnet, M.; Genitori, L. Surgery of complex craniofacial defects: A single-step AM-based methodology. Comput. Methods Programs Biomed. 2018, 165, 225-233. [CrossRef]

222. Cho, H.R.; Roh, T.S.; Shim, K.W.; Kim, Y.O.; Lew, D.H.; Yun, I.S. Skull Reconstruction with Custom Made Three-Dimensional Titanium Implant. Arch. Craniofacial Surg. 2015, 16, 11-16. [CrossRef] [PubMed]

223. Salmi, M.; Tuomi, J.; Paloheimo, K.; Björkstrand, R.; Paloheimo, M.; Salo, J.; Kontio, R.; Mesimäki, K.; Mäkitie, A.A. Patient-specific reconstruction with 3D modeling and DMLS additive manufacturing. Rapid Prototyp. J. 2012, 18, 209-214. [CrossRef]

224. Moiduddin, K. Implementation of Computer-Assisted Design, Analysis, and Additive Manufactured Customized Mandibular Implants. J. Med. Biol. Eng. 2018, 38, 744-756. [CrossRef]

225. Jo, Y.-Y.; Kim, S.-G.; Kim, M.-K.; Shin, S.-H.; Ahn, J.; Seok, H. Mandibular Reconstruction Using a Customized Three-Dimensional Titanium Implant Applied on the Lingual Surface of the Mandible. J. Craniofacial Surg. 2018, 29, 415-419. [CrossRef]

226. Qassemyar, Q.; Assouly, N.; Madar, Y.; Temam, S.; Kolb, F. Total nasal reconstruction with 3D custom made porous titanium prosthesis and free thoracodorsal artery perforator flap: A case report. Microsurgery 2018, 38, 567-571. [CrossRef] [PubMed]

227. Mangano, F.; Pozzi-Taubert, S.; Zecca, P.A.; Luongo, G.; Sammons, R.; Mangano, C. Immediate Restoration of Fixed Partial Prostheses Supported by One-Piece Narrow-Diameter Selective Laser Sintering Implants: A 2-year prospective study in the posterior jaws of 16 patients. Implant. Dent. 2013, 22, 388-393. [CrossRef]

228. Mangano, F.; De Franco, M.; Caprioglio, A.; Macchi, A.; Piattelli, A.; Mangano, C. Immediate, non-submerged, root-analogue direct laser metal sintering (DLMS) implants: A 1-year prospective study on 15 patients. Lasers Med Sci. 2013, 29, 1321-1328. [CrossRef]

229. Kumar Malyala, S.; Kumar, R.Y.; Alwala, A.M. A 3D-printed osseointegrated combined jaw and dental implant prosthesis-A case study. Rapid Prototyp. J. 2017, 23, 1164-1169. [CrossRef]

230. Cerea, M.; Dolcini, G.A. Custom-Made Direct Metal Laser Sintering Titanium Subperiosteal Implants: A Retrospective Clinical Study on 70 Patients. BioMed Res. Int. 2018, 2018, 1-11. [CrossRef]

231. Parr, W.C.; Burnard, J.L.; Singh, T.; McEvoy, A.; Walsh, W.R.; Mobbs, R.J. C3-C5 Chordoma Resection and Reconstruction with a Three-Dimensional Printed Titanium Patient-Specific Implant. World Neurosurg. 2019, 136, 226-233. [CrossRef]

232. Willemsen, K.; Nizak, R.; Noordmans, H.J.; Castelein, R.M.; Weinans, H.; Kruyt, M.C. Challenges in the design and regulatory approval of 3D-printed surgical implants: A two-case series. Lancet Digit. Health 2019, 1, e163-e171. [CrossRef]

233. Wei, F.; Li, Z.; Liu, Z.; Liu, X.; Jiang, L.; Yu, M.; Xu, N.; Wu, F.; Dang, L.; Zhou, H.; et al. Upper cervical spine reconstruction using customized 3D-printed vertebral body in 9 patients with primary tumors involving C2. Ann. Transl. Med. 2020, 8, 332. [CrossRef]

234. Eltes, P.E.; Kiss, L.; Bartos, M.; Gyorgy, Z.M.; Csakany, T.; Bereczki, F.; Lesko, V.; Puhl, M.; Varga, P.P.; Lazary, A. Geometrical accuracy evaluation of an affordable 3D printing technology for spine physical models. J. Clin. Neurosci. 2020, 72, 438-446. [CrossRef]

235. Park, J.W.; Song, C.A.; Kang, H.G.; Kim, J.H.; Lim, K.M.; Kim, H.-S. Integration of a Three-Dimensional-Printed Titanium Implant in Human Tissues: Case Study. Appl. Sci. 2020, 10, 553. [CrossRef]

236. Park, J.W.; Kang, H.G.; Lim, K.M.; Kim, J.H.; Kim, H.S. Three-Dimensionally Printed Personalized Implant Design and Reconstructive Surgery for a Bone Tumor of the Calcaneus. JBJS Case Connect. 2018, 8, e25. [CrossRef] 
237. Park, J.W.; Kang, H.G.; Kim, J.H.; Kim, H.-S. New 3-dimensional implant application as an alternative to allograft in limb salvage surgery: A technical note on 10 cases. Acta Orthop. 2020, 91, 489-496. [CrossRef]

238. Angelini, A.; Trovarelli, G.; Berizzi, A.; Pala, E.; Breda, A.; Ruggieri, P. Three-dimension-printed custom-made prosthetic reconstructions: From revision surgery to oncologic reconstructions. Int. Orthop. 2018, 43, 123-132. [CrossRef]

239. Liang, H.; Ji, T.; Zhang, Y.; Wang, Y.; Guo, W. Reconstruction with 3D-printed pelvic endoprostheses after resection of a pelvic tumour. Bone Jt. J. 2017, 99B, 267-275. [CrossRef] [PubMed]

240. Kamel, M.K.; Cheng, A.; Vaughan, B.; Stiles, B.; Altorki, N.; Spector, J.A.; Port, J.L. Sternal Reconstruction Using Customized 3D-Printed Titanium Implants. Ann. Thorac. Surg. 2019, 109, e411-e414. [CrossRef] [PubMed]

241. Goldsmith, I.; Evans, P.L.; Goodrum, H.; Warbrick-Smith, J.; Bragg, T. Chest wall reconstruction with an anatomically designed 3-D printed titanium ribs and hemi-sternum implant. 3D Print. Med. 2020, 6, 1-7. [CrossRef]

242. Turna, A.; Kavakli, K.; Sapmaz, E.; Arslan, H.; Caylak, H.; Gokce, H.S.; Demirkaya, A. Reconstruction with a patient-specific titanium implant after a wide anterior chest wall resection. Interact. Cardiovasc. Thorac. Surg. 2013, 18, 234-236. [CrossRef] [PubMed]

243. Mertz, L. Dream It, Design It, Print It in 3-D: What Can 3-D Printing Do for You? IEEE Pulse 2013, 4, 15-21. [CrossRef] [PubMed]

244. Abdulhameed, O.; Al-Ahmari, A.; Ameen, W.; Mian, S.H. Additive manufacturing: Challenges, trends, and applications. Adv. Mech. Eng. 2019, 11, 1687814018822880. [CrossRef] 